\title{
El poder feudal como origen de hidalguía en la Baja Edad Media castellana: un ejemplo del señorío de Villena
}

\author{
LUIS Díaz DE LA GuARDIA Y LÓPEZ \\ UNED (C.A. Motril)
}

\begin{abstract}
RESUMEN
ABSTRACT

Tras analizar las posibles fuentes de creación de la nobleza en Castilla durante la Edad Media, el presente artículo se detiene en el estudio del poder feudal como origen de nobleza para terceros, resaltando que éste posee mayor significado en las épocas en que el poder de la Monarquía se debilita en favor de

otros poderes del reino. Desde esta concepción se procede a analizar un caso concreto ocurrido en el señorio de Villena bajo el gobierno de López Pacheco en la segunda mitad del siglo $X V$, reinando en Castilla Enrique IV.

\section{PALABRAS CLAVE}

Baja Edad Media, nobleza, hidalguia, caballería, fuentes de creación de nobleza, poder feudal, Diego López Pacheco, marqués de Villena, Juan de la Peña, Montalbanejo, Belmonte, señorio de Villena, Corona de Castilla, Archivo Histórico Nacional, Archivo de la Real Chancilleria de Granada.

After studying the possible sources of creation of nobility in Castile during the Middle Ages, this article centers on the study of feudal power as origin of nobility for others, emphasizing that this power has major significance during the period when the Monarchy is weakening in favor of other powers of the kingdom. Starting from this conception it is studied a particular case which happened in the marquisate of Villena under the government of Lopez Pacheco in the second half of the XV century, during the reign of Enrique IV in Castile.

\section{KEY WORDS}

The Early Middle Ages, nobility, cavalry, sources of creations of nobility, feudal power, Diego López Pacheco, marquis of Villena, Juan de la Peña, Montalbanejo, Belmonte, the marquisate of Villena, Reign of Castile, The National Historical Archive, The Royal Chancellery Archive of Granada.
\end{abstract}


Ante las fuentes existentes, resulta difícil desentrañar con precisión el origen último de la nobleza castellana, pese a los intentos ya realizados por grandes historiadores que estudiaron tanto esta problemática en general como aspectos particulares de ella, como puede ser el origen de la hidalguía castellana ${ }^{1}$. $\mathrm{Y}$, sin contradecir esto, sin embargo se pueden y se deben estudiar con mayor detenimiento las fuentes de creación de la nobleza y sus mecanismos, una vez establecida y asumida ésta como un hecho. Por tanto, no buscan estas páginas proseguir semejante estudio sobre el origen último de la nobleza, sino analizar, desde un caso concreto, una de las fuentes posibles de la hidalguía castellana, uno de sus orígenes, establecida y asumida ya la hidalguía como un hecho social y jurídico consolidado en la Corona de Castilla durante la Edad Media, y para lograr este fin se debe en primer lugar analizar de qué nobleza se habla y proponer en conjunto las posibles fuentes de origen o creación de la nobleza castellana.

\section{LA LLAMADA NOBLEZA POLÍTICA CASTELLANA}

Pese a que muy prontamente debió existir en la conciencia social una clara diferenciación - sin obviar los importantes discursos ideológicos sobre los que se volverá- entre el ser noble a través de la virtud y el ser jurídicamente noble, resulta plausible que sea ya en la frontera entre el siglo XII y XIII cuando esa diferenciación se hace más manifiesta y a la vez se presenta de forma más estructurada en su discurso. Por ejemplo don Juan Manuel en su Libro de los Estados reconoce la posibilidad de la salvación a través de la virtud, a través de la nobleza personal, en cualquier estado y, aproximándose aún más a la diferenciación de distintos tipos de nobleza, distingue dentro del Orden de los Defensores entre los nobles de sangre - desde emperadores hasta infanzones, todos hijosdalgo-y los defensores no nobles pero virtuosos por sus hechos y dedicaciones, a través de los cuales pertenecen al Orden más esclarecido de los llamados por él legos:

1 Recuérdese, por ejemplo, la muy antigua problemática sobre la aparición de la hidalguía castellana, de su origen e incluso del origen del término, que ocupó a teóricos, nobiliaristas, etc., desde tiempos remotos, intentos de solucionar un interrogante que se ha mantenido hasta nuestros días, ya desde perspectivas científicas, y de los que son exponente nombres como Hinojosa, Menéndez Pidal, Américo Castro, Sánchez-Albornoz, Lázaro Carreter, Carle, Pérez de Tudela, etc. Grandes intelectuales que desde distintas facetas y disciplinas han pretendido desentrañar ese origen, buscando además evoluciones lógicas y con cierta continuidad. Debate que incluso ha protagonizado agrias disputas, disputas en ocasiones insertas en otras aún mayores y de las que son una pequeña muestra las palabras de Sánchez-Albornoz, publicadas por primera vez en 1951 en sus Cuadernos de Historia de España, contra la tesis de Américo Castro sobre el origen de los hijosdalgo: "Sólo me he propuesto aquí probar el grave error de Castro al vincular los banu al jamas o hijos de los quintos con los fijosdalgo, error que le señalé amistosamente antes de que apareciera España en su Historia. ¿Se decidirá a reconocerlo, o, more hispanico-recordemos el "Sostenello y no enmendallo" clásico - escribirá su quinto alegato en pro de una tesis sin base alguna en la realidad histórica?», SÁNCHEZ-ALBORNOZ Y MENDUIÑA, C: «¿De los Banu Al-Jamas a los Fijosdalgo?», en SÁnCHEz-Albornoz, C.: Estudios polémicos, Madrid, Espasa Calpe, 1979, pág. 243. Últimamente han vuelto a ser criticadas las tesis de Castro sobre la hidalguia castellana, ahora desde su vertiente semítica, concretamente en NETANYAHU, B: De la anarquía a la Inquisición. Estudios sobre los conversos en España durante la Baja Edad Media, Madrid, La Esfera de los Libros, 2005, pp. 21-51. 
«Et en pos éstos, ay otros defensores que non son fijos dalgo... los otros omnes que biven en las villas, que no son omnes fijos dalgo nin biven por mercaduría nin por menesteres que fagan que labren por sus manos, que son omnes que andan en la guerra... Et todos los que son tenidos por defensores pueden salvar las almas en sus estados" ${ }^{2}$. Línea de pensamiento que terminará estableciendo tres distintos tipos nobiliarios, tres tipos de nobleza: moral, política y teologal. División nobiliaria que, ya un poco estancada y rancia y casi dedicada en exclusiva a la autocomplacencia de los hidalgos, fue incorporada por los nobiliaristas y teóricos políticos hasta el fin del Antiguo Régimen en el siglo XIX.

Estas diferenciaciones en la esencia misma de la nobleza y en sus diferentes concepciones permitieron, sin duda, en la práctica, desde lo más cotidiano, por un lado a la población no noble reconocer al noble jurídicamente investido, a sus privilegios y deberes -no necesariamente acatar esto sin discusión-, y, por otro, al noble sentirse tal, independientemente de sus actos pues existían un conjunto de facultades y obligaciones protegidas por la norma de las que era titular y las cuales no solo acataba la sociedad teóricamente sino que además estaban respaldadas por el poder estatal en cualquiera de sus formas. Junto a esto y dentro de bajas y altas disquisiciones, eran por todos necesariamente reconocidas otras noblezas, radicadas éstas en la verdadera condición y comportamiento del individuo y no en la salvaguardia de un linaje o de un proceder del poder. Noblezas esencialmente virtuosas que podrían permitir a su titular el acceder a la nobleza jurídica, pero noblezas basadas en la virtud cuyo premio más que encontrarse en la sociedad y en lo terreno, se encontraba en el mundo celestial, en una recompensa post-mortem de naturaleza divina. Sin duda, en cualquier caso, válvula de escape ideológica para todos aquellos no agraciados por la nobleza institucional y, al mismo tiempo, también parapeto ideológico sobre el que mantener ciertas estructuras de poder por parte de sus titulares ${ }^{3}$.

2 Don Juan Manuel: El libro de los Estados, edición de lan R. Macpherson y Robert Brian Tate, Madrid, Clásicos Castalia, 1991, pp. 277-278. Alfonso X establece en las Partidas la existencia de diversas noblezas entre los gentiles, noblezas que con la evolución del discurso nobiliario serán entendidas sobre todo en el Renacimiento y en la modernidad, más que como tipologías, como vías a través de las cuales alcanzar la nobleza jurídica o política como sostiene ya Gregorio López, fundamentándose en Baldo de Ubaldis, en su glosa al siguiente párrafo de las Partidas que sin embargo expresa claramente que el legislador no habla tan sólo de fuentes sino también de tipos de gentileza: "E tomaron este nome de gentileza (por nobleza), que muestra tanto como nobleza de bondad: porque los gentiles fueron omes nobles e buenos: e bivieron más ordenadamente que las otras gentes. E esta gentileza avian en tres maneras. La vna por linage. La otra por saber. La tercera por bondad de costumbres e de maneras", Partidas 2, 21, 2.

3 La teoría cerrada de los Tres Órdenes, sin ser rechazada en algún modo, necesitaba cierta laxitud que permitiera expectativas de mejora en la mayoría de la población aunque éstas fueran celestiales, quizá las más idóneas para los mismos defensores de los Tres Órdenes. Ciertas esperanzas siempre preconizadas por el cristianismo y por los grandes padres que influirán en el medievo, así dice san Angustín en el siglo iv: “Habrá alli verdadera gloria, no siendo ninguno alabado por error o lisonja del que le alabare. Habrá verdadera honra que a ningún digno se negará, ni a ninguno se le dará; pero ninguno que sea indigno la pretenderá por ambición, porque no se permitirá que haya alguno que no sea digno. Alli habrá verdadera paz, porque ninguno padecerá adversidad, ni de si propio ni de mano de otro. El premio de la virtud será el mismo Dios que nos dio la virtud, pues a los que la tuvieren les prometió a sí mismo, porque no puede haber cosa ni mejor ni mayor", SAN AGUStiN: La ciudad de Dios, Introducción de Francisco Mon- 
Pero pese al pretendido inmovilismo social que, fundamentándose entre otros en Aristóteles, establece la necesaria recompensa al virtuoso, al noble no pertenenciente a la nobleza política, en un más allá en donde disfrutará de honras y bienes muy superiores a cualquier cosa terrena y que como he dicho es elemento pacificador de las grandes y evidentes diferencias entre los hombres, casi imposibles de superar, existe también un discurso motivado por la realidad más palpable que alimenta esperanzas terrenas para los que ejercitan la virtud pero no están agraciados con el privilegio nobiliario. Ese discurso se basa sin duda en la mutabilidad de la fortuna. Mutabilidad que puede alcanzar a los mismos reyes como ocurre en el Libro de Apolonio:

El estado d'est' mundo siempre asi andido,
cada día se camia, nunca quedo estido
en toller e en dar, es todo su sentido
vestir al despojado, despojar al vestido ${ }^{4}$.

Fortuna no sólo negativa sino que es también camino por el que algunos pueden salir de esa deplorable situación en la que se encuentran, pues como dice el mismo Libro de Apolonio refiriéndose a Dios: «El que hobo poder de pobre te tornar

tes de Oca, México, Editorial Porrúa, 2000, pág. 601. San Anselmo, ya en pleno Medievo, nos advierte siguiendo al Antiguo Testamento - p.e. Proverbios 8, 18-21,24-que Dios es fuente de toda merced, "Si honor y riquezas, Dios establecerá sobre muchas riquezas a sus siervos buenos y fieles, más aún, serán llamados hijos de Dios y de dioses, y donde esté su Hijo alli estarán y serán herederos de Dios y coherederos de Cristo", SAN Anselmo: "Proslogion", en SAN ANSELmo: Proslogion. Sobre la Verdad, prólogo de Antonio Rodriguez Huéscar y traducción de Manuel Fuentes Benot, Barcelona, Ediciones Orbis, 1984, pág. 88. Igualmente el popular Viaje de San Brandán, nuestro san Borondón, presenta al común un paraiso repleto de bienes eternales, permanentes y tan opuestos a los bienes y honras terrenales, tan movedizas, "Quien alli habite no padecerá ninguna pena, ni conocerá ninguna cosa hostil: ni galerna, ni calor, ni frío, ni congoja, ni hambre, ni sed, ni penuria. Tendrá tal abundancia de riquezas que sobrepasarán su apetencia; tampoco las podrá perder porque son seguras", BENEDEIT: EI Viaje de San Brandán, traducción y prólogo de Marie José Lemarchand, Madrid, Ediciones Siruela, 1986, pág. 58. Por último aunque santo Tomás defiende -también san Anselmo- la existencia casi inamovible de los Órdenes: «Por la misma razón y entre los hombres mismos, se da un orden; porque quienes resaltan por su capacidad intelectual son quienes por naturaleza gobiernan; quienes son robustos físicamente, pero no bien desarrollados intelectualmente, parecen destinados por naturaleza a servir, como dice Aristóteles en la Política" TOMÁS DE AQUINO: Suma contra los gentiles, traducción y estudio introductivo por Carlos Ignacio González, S. J., México, Editorial Porrúa, 1998, pág. 408; igualmente el Aquinate reconoce que la felicidad verdadera de todo hombre es la contemplación de la divinidad, muy superior a cualquier felicidad terrena, y que esa única felicidad verdadera es propia del virtuoso, no del noble o del rico, sino del virtuoso y que incluso el rey ha de procurarla para todos sus súbditos: "es propio de la tarea del rey por tal motivo procurar que la sociedad viva rectamente, de modo adecuado para conseguir la felicidad celestia!, como por ejemplo ordenará lo que lleve a tal felicidad y prohibirá lo que se le oponga, en cuanto sea posible", SANTO TOMAS DE AQUINO: La monarquía, Barcelona, Altaya, 1997, pág. 76.

${ }^{4}$ ANónImo: Libro de Apolonio, Introducción, edición y notas de Manuel Alvar, Barcelona, Planeta, 1984, pp. 21-22. Mudanza social que es una constante en nuestra literatura y en nuestro pensamiento. Dice el marqués de Santillana: "iQuántos ricos son venidos / en pobreza, / e de soberana alteza / desçendidos! ¡Quántos fueron escarnidos, confiando / d'este loco e poco mando, / e perdidos!», MAROUÉs DE Santillana: Poesías completas, edición de Maxim P.A.M. Kerkhof y Ángel Gómez Moreno, Madrid, Clásicos Castalia, 2003, pág. 422. Creencia en bienes mudables y perecederos que se comparte y difunde también por la música como refiere el siguiente villancico de Juan del Encina «Todos los bienes del mundo / pasan presto y su memoria / Salvo la fama y la honra", en Plaser y gasajo. Música cortesana en tiempos del Papa Alejandro VI, Alboraia (Valencia) Tabalet Estudios, 2000. 
/ puédete si quisiere de pobreza sacar " ${ }^{5}$. Los labriegos y campesinos tenían ejemplos reales entre sus convecinos al observar cómo familias de su igual condición gracias a su actividad y aumento de riquezas tornábanse caballeros, villanos sí, pero caballeros y privilegiados, e igualmente verian cómo otros, incluso, por las artes que fuesen, llegaban a engrosar la nobleza política ${ }^{6}$. Era por tanto otra vía dirigida a la población y que si era terrenalmente palpable: la posibilidad de superar socialmente nacimiento y condición. Y por tanto también era instrumento ideológico al ser-

5 ANÓNIMO: El libro... pág. 22.

- La nobiliaria siempre criticaria y tendría como secundaria esta nobleza en caso de conocerse su pasado originario, verbi gratia un privilegio de hidalguia, incluso en tiempos de Felipe IV y de las desafortunadas remodelaciones nobiliarias del conde-duque se pretendió hacer uso, para compelerlos aún más, de la existencia de estos privilegios y de la posibilidad de revocarlos puntualmente en caso de que no cumplieran sus desiginios alguno de los descendientes de los agraciados. Igual ocurre, cierto desprecio o minusvaloración, con las noblezas que fueron sometidas a procesos de hidalguía. Este discurso nobiliario no desinteresado en modo alguno, desgraciadamente ha sido tomado como dogma de fe por buena parte de la historiografía actual. Pero el día a dia de la documentación no señala tal y menos de modo absoluto. Volviendo al puro ascenso social y a la entrada por un medio u otro en la nobleza política, tanto por nobiliaristas, que en sus discursos tienden a presentar una tónica descendente desde lo que consideran lo más noble a lo simplemente noble (los hidalgos sin más) como por la historiografia que suele beber de estas fuentes doctrinales con cierto poco espiritu crítico, cosa que sí se hace por ejemplo con fuentes políticas o juridicas, etc., lo cierto es que también se consideran a estos ennoblecimientos como casi dignos de conmiseración y a veces hasta ridiculos al compararlos con grandes magnates, grandes casas nobiliarias, etc., pero se olvida que para los labriegos de un determinado lugar o para los criados no nobles de un gran señor - para la mayoria de la población- era mucho más que suficiente. y agrias penalidades, disputas y sacrificios se dieron y soportaron para conseguirlo, para subir ese, para muchos historiadores, pequeño escalón social y jurídico que no sólo auguraba mejoría en el titular sino grandes posibilidades, aún mayores, para sus descendientes, y que suponía un gran y rotundo triunfo. Ascensos que, por cierto, serían envidiados y apetecidos por aquellos que los rodeaban y no lo habian conseguido. Sin desdecir lo anterior y pese a que los privilegios de hidalguia equiparaban expresamente al beneficiado y a sus descendientes a los hidalgos castellanos cuyo origen era inmemorial, es cierto que los nuevos nobles sufrieron en determinadas circunstancias recortes de hecho y Derecho a esta equiparación primigenia, sobre todo en la Edad Moderna, por ejemplo al estarles vedados, en ocasiones, ciertos honores como su ingreso en determinadas corporaciones nobiliarias, o por ejempio al obligar a que constara -pese a que quizá el beneficiado por el privilegio había muerto hacia siglos- su condición de nobles de privilegio frente a los nobles cuyo crigen de la nobleza era olvidado y por tanto disfrutaban de una hidalguia de sangre inmemorial. Estas diferencias incluso sirvieron de arma arrojadiza entre bandos nobiliarios que deseaban el poder local. Acaeció entre otros sitios en la villa de Llerena entre 1598 y 1601. Existiendo pleito de mitad de oficios -demandada la mitad de oficios por los nobles contra los pecheros- como es lógico los pecheros se oponían a esta institución, pero lo que resulta sorprendente es que los nobles demandantes estaban divididos en su conquista del poder. Los nobles que no eran de privilegio solicitan a la Chanciilería de Granada que aunque "los que se deçian hixosdalgo de previlexio pretendian ser admitidos en el Estado de Hixosdalgo de Sangre... en la eleçión de los tales ofiçios que se dieren no hadmitiesen a los que se deçían ser hixosdalgo de previlexio, sino que los admitiesen en el Estado de los Pecheros". La mitad de oficios se concedió pero en las sentencias chancillerescas, la última de 27 de septiembre de 1601, se ordenó, como no podía ser de otra forma, que tanto los de sangre como de privilegio conformasen el Estado de los Hijosdalgo de Llerena, eso sí, tildando a unos de sangre y a otros de privilegio. Evidencia de pugnas en cuanto al origen de noblezas, pero más aún evidencia de instrumentalización de lo último para no compartir el poder, poder que pretendian disfrutar los llamados hidalgos de sangre encabezados por don Pedro de Paz y Mendoza y poder que veían peligrar si lo habian de repartir con los hidalgos de privilegio, pues éstos estaban acaudillados por Marco Antonio Becerra, capitán general de Infantería Española y de Arcabuceros, que lo había sido en el reino de Nueva Granada, y que además era familiar del Santo Oficio, Archivo de la Real Chancillería de Granada (ARChG), Hidalguia, caja 5.074, pieza 363. Y, de nuevo, todo esto no desmiente que para la inmensa mayoría de la población, que en sueños puede que quisiera ser un gran y rico marqués, ser hidalgo aunque fuese de privilegio era un gran y apetecido salto social, pese a críticas pretéritas 0 , incomprensiblemente, más que análisis, criticas actuales. 
vicio del poder, pues éste conocía que los muy determinados y poco numerosos ascensos a lo más alto de la sociedad no le harian daño y menos aún el ascenso de individuos a los bajos escalones de la estructura social noble, sino que le asentarían aún más como estructura conformadora y dirigente de la sociedad.

Nobleza política, por tanto, entendida como aquélla que está sometida al Estado -Estado siguiendo a Mitteis y su escuela - que el Estado crea, ampara y regula, cuya creación se supone deriva del poder soberano y que en principio debe estar al servicio de él, creación que puede ser conocida - privilegio-o desconocida - nobleza de sangre inmemorial- pero que en cualquier caso se supone - pese a discursos de todo tipo- que en última instancia está creada por el Estado y sometida jurídicamente a él.

De esta nobleza política, de la que se ha referido que independientemente del nacimiento, se podía llegar a pertenecer y a la que muchos ansiaban pertenecer, es de la que tratan estas páginas. Una nobleza política que, aunque así se llamó en su momento, prefiero denominarla jurídica, pues tal denominación en modo alguno desvirtúa a la misma si no que a mi juicio la concreta y esclarece aún más con respecto a nuestros tiempos. Y esto, porque la nobleza política, independientemente de discursos, es una institución jurídica y por lo tanto regulada e inserta en nuestro ordenamiento juridico histórico y que además fue aceptada siempre y tenida por tal, institución que necesita de estudios sistemáticos tanto de contenido y efectos, como de sus fuentes creadoras.

Pero si esto es cierto, la existencia de una nobleza jurídica, también lo es que bajo esta cobertura normativa y teórica, existe una realidad que la justifica y que la alimenta, realidad varia que puede englobarse en el modelo de vida denominado noble, del que, sobre todo para el medievo, queda mucho por investigar, pues aunque existan unos posibles patrones comunes, el casuismo regional o territorial dentro de la Corona de Castilla invita a pensar en circunstancias no siempre compartidas ${ }^{7}$.

7 Desconocemos, salvo las más comunes, aún muchas de las formas de vida cotidianas de estos hidalgos medievales. Hábitos, comportamientos, dedicaciones y costumbres que nos facilitarían una verdadera aproximación a elios desde la Historia, la Antropología, la Política, la Economía, el Derecho, etc. Sin embargo, los datos, posiblemente muy dispersos, están ahí y los pleitos de hidalguía, a través de las probanzas de testigos de hasta la primera mitad del siglo xVi, serian, entre otras, una buena fuente para conocer muchos de estos aspectos hoy olvidados por lo que se refiere a la Baja Edad Media Castellana. No se trata de buscar genealogías, a las que dependiendo de los hechos o de las corrientes historiográficas se les da mayor o menor veracidad y significado, sino de conocer comportamientos y sucesos que fueron dados por creíbles y como propios de nobles por la sociedad y los jueces de esos siglos, independientemente de que a cada caso concreto, por lo que respecta al linaje o la persona, se le deba dar credibilidad o no. Sirva de ejemplo, uno entre miles, lo contenido en una ejecutoria de la Chancillería de Granada dada el 16 de marzo de 1519 a favor de la hidalguía de los hermanos Diego, Juan y Rodrigo de Colmenares, naturales de la villa de Moclín e hijos de su antiguo alcaide. En ella los testigos deponen sobre el abuelo de los litigantes - como prescribía la ley - un hidalgo, al servicio de los Mendoza, llamado Rodrigo de Colmenares y que vivió a mediados del siglo xv en Villanuño. En la ejecutoria, entre otras afirmaciones de los testigos, se recoge la siguiente práctica funeraria propia de hidalgos: «E que al tiempo que le conosçiera este testigo, estava biudo el dicho Rodrigo de Colmenares, e no le conosçiera sino quatro o çinco años. E quando fallesçiera, viera este testigo, que quebraran quatro o çinco paveses e lanças como por hidalgo e prinçipal del dicho lugar», Biblioteca Nacional (BN) Manuscritos, manuscrito 11.494. 
El modelo de vida noble medieval sin duda estuvo cerca del binomio nobleguerrero y de las virtudes que a él se le atribuian, muchas de las cuales debieron ser adoptadas del discurso caballeresco, no siempre estrictamente propio de la nobleza de sangre, o cuando menos no del todo asimilable a ella, al igual y del mismo modo que muchos de los privilegios que finalmente se atribuyó la caballería provienen de la institución nobiliaria, de lo que el fuero de Castrojeriz es un temprano ejemplo ${ }^{8}$.

Noble guerrero que en principio debe poseer cierto poder económico para mantenerse en un perfecto equilibrio, pues aunque parece real y también lógico que con el devenir del tiempo, muy pronto, se debió dar el fenómeno del noble pobre, del hidalgo pobre, que no pierde su condición gracias al amparo jurídico, también existen evidencias en nuestra normativa nobiliaria más antigua conservada de la posibilidad de renunciar a la nobleza precisamente por causa de no poseer recursos suficientes para vivir conforme a ella y dentro de sus prácticas, norma que en ese caso de pobreza estipula la siguiente ceremonia, por otro lado totalmente voluntaria:

Sepades que quiero ser vostro vecinno en infurción e en toda facienda vostra; e aduxere una aguijada, e tovieren la aguijada dos omes en los cuellos, e pasare tres veces sobre ella e dijier, dexo nobredat e torno villano. E estonces será villano, e quantos fijos e fijas tovier en aquel tiempo todos serán villanos. E quando quisier tornar a nobredat, venga a la Igresia, e diga en Conceio; dexo vostra vecindat, que no quiero ser vostro vecino; e trocier sobre el aguijada diciendo: dexo villanía e tomo nobredat. Estonces será nobre, e quantos fijos e fijas fecier, abrán quinientos sueldos e serán nobres ${ }^{9}$.

Noble medieval que, pese a sentirse atraido ya inicialmente por los núcleos de población que surgen con la Reconquista, está abocado a vivir o en pugna o al margen del fenómeno urbano. La inmensa mayoría de los fueros castellanos reflejan prohibiciones de su asentamiento como tales en las nuevas localidades, sal-

${ }^{8} \mathrm{Si}$ en Castrojeriz los caballeros villanos recibían las mercedes de los infanzones, en Ciudad Real y otros lugares los caballeros nobles recibian las mercedes muy favorables de los caballeros de Toledo, mercedes que se habian creado para mozárabes, castellanos y francos pero $a b$ initio sin atender a su naturaleza hidalga o no: "Et yo sobre dicho rey don Alfonso otórgoles e doles para siempre jamás e a todos los moradores que fuesen en esta Villa Real la sobre dicha e en todo su término que hayan el fuero de Cuenca en todas cosas. Et do de mejoria a los caballeros dalgo que hy moraren que hayan aquellas franquicias en todas cosas que han los caballeros de Toledo", PÉREz MARCOS, R: "Fueros, cartas pueblas y privilegios de concesión real en Castilla-La Mancha (siglo XIII-XIV)", en ALVARAdo Planas, J (Coord.): Espacios y fueros en Castilla-La Mancha (siglos Xi-xv) Una perspectiva metodológica, Madrid, Ediciones Polifemo, 1995, pág. 169. Cambios que confirman en buena medida que algunos de los regímenes locales que tanto fiscalmente como en otras materias se habian configurado a favor de los caballeros villanos eran en su conjunto sumamente positivos, tanto que incluso se podian otorgar a los caballeros de condición hidalga a modo de merced que recompensara el binomio residente en ellos consistente en la unión de un servicio caballeresco sobresaliente con su condición noble. Lo que implica que en la evolución de la configuración de las facultades, nunca generales sino territoriales, que adornaban a los hidalgos castellanos también se benefició ésta de facultades no del todo originariamente nobiliarias, sino ciudadanas y creadas a favor de la caballeria villana. Enriquecimiento institucional por tanto en ambos sentidos.

${ }^{9}$ Fuero Viejo (F.V.) $1,5,16$. 
vo que renunciaran a su fuero nobiliario y asumieran como cualquier otro vecino el fuero local, lo que equivalía a gozar de la vecindad y de ciertos privilegios, pero también equivalía a la renuncia a la hidalguia y su introducción de hecho en la villanía, salvo que una vez establecido como vecino se negara a cumplir el fuero y lo jurado y se comportara como hidalgo y defendiera sus derechos como tal. Los fueros son explícitos en su conversión a la villanía de facto y a cumplir el fuero del lugar. Dice el fuero de Castroverde de Campos, dado en León el 7 de enero de 1199, en su precepto vigesimoprimero:

Si hidalgus in Castroviride vicinus fuerit, ille et uxor eius talem forum habeant sicut vicini sui ${ }^{10}$.

Preceptos que se cumplieron -es imposible conocer su cuantía- por aquellos hidalgos que por las razones que fuesen necesitaban ser comprendidos entre los vecinos, no como simples moradores, sino como verdaderos vecinos, $y$ vecindades que son otorgadas bajo condiciones, sometidas a veces a la temporalidad, pero que obligan a someterse al fuero del lugar y sobre todo en sus aspectos financieros y tributarios ${ }^{11}$.

10 Rodríguez Fernández, J: Los fueros locales de la provincia de Zamora, Salamanca, Junta de Castilla y León, 1990, pág. 307. Los ejemplos son casi infinitos, asi el rey Alfonso IX al otorgar fuero, el 12 de octubre de 1208, al concejo de Belver de los Montes, dispone: “Si fidalgus in Belveer vecinus fuerit, ille et uxor eius et filii sui tale forum habeant sicut vicini sui», Idem, pág. 317. Casos muy numerosos y de numerosas zonas de Castilla, manda el fuero de Uclés dado en Toledo en marzo de 1179: «Infanzones qui venerint al Ucles populare, tales calumpnias habeant de morte et de vita quomodo alios populatores. Infanzones qui intrare in termino de Ucles de los moiones adentro, tales foros habeant quomodo alios vicinos de Ucles», MARTín, J. L.: "Los fueros de la Orden de Santiago en Castilla-La Mancha", en ALvaRAdO Planas, J. (Coord.): Espacios y fueros en Castilla-La Mancha (siglos Xi-XV) Una perspectiva metodológica, Madrid, Ediciones Polifemo, 1995, pág. 195. Ejemplos que por cierto no se limitan siempre a poblaciones pequeñas. Dice el fuero de Sahagún dado el 18 de diciembre de 1152 por el rey Alfonso VIl y el abad Domingo: "Et quicumque nobilis vel cuiuslibet dignitatis in villa Sancti Facundi in propia vel aliena domo havitaverit, ipse et quicumque cum eo fuerit, habeat forum ville, sicut unuquisque de vicinis", Rodriguez Fernández, J.: Los Fueros del Reino de León. / Documentos, Madrid, Ediciones leonesas, 1981, pág. 73

11 Sirva de muestra el siguiente documento en donde un hidalgo llamado Pedro Sánchez de Cañete se obliga, el 23 de diciembre de 1435, a contribuir a condición de ser admitido como vecino del lugar de las Majadas: "Sepan quantos este público instrumento vieren como en la çibdat de Cuenca veinte e tres dias del mes de desienbre, año del nasçimiento del nuestro señor lhesu Christo de mil e quatroçientos e treynta e çinco años, en presençia de mí Martín Lopes de Bolliga, escrivano de nuestro señor el rey e su notario público en la su Corte en todos sus regnos e de los testigos de yuso escriptos, paresçió presente Pero Sanches de Cañete e dixo que por quanto él hera vesino e se avía avesindado antes de agora en las Majadas, lugar de Sancho de Jarava, e agora como primeramente que se avesindava e avesindó en el dicho lugar las Majadas con el conçejo e omes buenos pobladores e vesinos e moradores del dicho lugar, que absentes estavan, a saber conviene por dies años conplidos primeros e avenideros de la fecha de este público instrumento e que se onbligava e obligó por sy mesmo e por todos sus bienes, así muebles como rayses, avidos e por aver por comoquier que los oy día ha e aver deva en qualquier manera para pechar e dar e pagar con el dicho conçejo e omes buenos pobladores e vesinos e moradores del dicho lugar Las Majadas, todos los pechos e trebutos e derechos acostunbrados e perteneçientes e devidos pagar al dicho Sancho de Jarava, señor del dicho lugar Las Majadas. E por la forma e manera que el dicho conçejo e omes buenos, vesinos e moradores del dicho lugar e cada uno de ellos to ha usado e acostunbrado e usaren e acostunbraren pagar de aqui adelante e en los tienpos pasados todos los otros pechos e derechos pertenesçientes e devidos pagar en qualquier manera que el dicho conçejo usa e acostunbra derramar entresy, asy para sus menesteres como para otras qualquier 
Y preceptos que llegan más allá al prohibir ventas e incluso tratos de diverso tipo y calidad con los hidalgos y en general con cualquier privilegiado que no lo fuera por el fuero local. El 3 de noviembre de 1310 daba fuero a la villa de Ifanes el abad James de Moreruela, ordenando en su precepto sexto, sobre la transmisión de bienes raíces dentro del término de la villa, lo siguiente:

Otrosi selo quisier vender, que lo venda a tal ome que vos faga el fuero e sea vestro vasallo commo sobredicho es, nin sea clerigo nin cavalero nin fidalgo ni rica duena ni donçella nin ome de orden nin ome de Tras Muro nin ome que reconat fuero, mas sea tal ome que more personalmiente en el lugar, asi commo sobredicho es ${ }^{12}$.

Prohibiciones forales, todas, creadas en primer lugar en beneficio de los entes repobladores de naturaleza feudal pero igualmente en beneficio de los grupos de poderosos que pronto surgen en cada localidad, cuando menos en relación con sus vecinos y demás repobladores ${ }^{13}$.

cosas que pertenesçientes y nesçesarias sean para pro común del dicho conçejo e vesinos e pobladores $\epsilon$ moradores del dicho lugar e cada uno de ellos en todo el dicho tienpo de los dichos dies años que la dicha vesindat a de durar. E dixo que se obligava e obligó de tener e guardar e conplir todo lo sobredicho e cada cosa de ello, sopena de dos mil maravedís de esta moneda usual de Castilla, que dos blancas fasen, e mil para el dicho Sancho de Jarava. La qual dicha pena tantas vegadas pueda ser demandada e sea tenido a la pagar quantas veses fuere o viniere contra lo sobredicho e cada cosa de ello e ençima que lo sobredicho e cada cosa de ello syenpre sea firme e estable e valedero. Para lo qual guardar e tener e conplir el dicho Pero Sanches dixo que obligava e obligó a los dichos sus bienes segund dicho es e por más firmesa renunçió e partió de sy toda ley e todo fuero e todo derecho canónico, çevil e costunbres e a todas las leyes de odenanças reales de que él se pudiese ayudar e anparar en rasón de las cosas que dichas son e señaladamente de la pena e en espeçial renunçio e partió de sy a la ley que dise que general renunçiaçión non vala salvo sy en espeçial esta ley non es renunçiada que en espeçial asy la renunçió e se partió de ella. De lo qual otorgó e mandó faser este instrumento público por la forma que de susodicho e declarado es. En que rogó a mi el dicho Martin Lopes, escrivano, que los escriviese e fisiese escritura e lo signase de mi signo. De que fueron testigos presentes, Garçía de Jarava e Diego de Villaguera, escudero del dicho Sancho de Jarava, e Martín Lopes de Bolliga, escrivano del rey. Fecho e otorgado fue este público instrumento en la dicha çibdat de Cuenca, día mes e año susodicho. Va escrito entre renglones e dis el dicho. E yo Martín Lopes de Bolliga escrivano e notario público susodicho del dicho señor rey en la su Corte e en todos los sus regnos fuy presente a todo lo susodicho en uno con los dichos testigos. E a pedimiento del dicho Sancho de Jarava lo escreví e dis aqui éste mio signo en testimonio de verdat. (Signo) Martín Lopes, escrivano", Archivo Histórico Nacional (AHN), Consejos, Leg. 44.503 .

12 Lo sobredicho no era otra cosa que el cumplimiento del mismo fuero de la villa de Ifanes que se estaba otorgando, Rodriguez. FERNANDEZ, J.: Los fueros locales..., pág. 394. La pena que llevaba esta transmisión de bienes raices a un hidaigo podía acarrear no sólo la pérdida de la propiedad y de lo percibido como pago, para ambas partes, sino incluso la pérdida de vecindad, como manifiesta el Memorial de los fueros de Pino de Babia, elaborado entre 1313 y 1324: "E todo onbre fijodalgo que comprar heredad en Pinos o en Santo Millano que la pierda, e otro tal que se alguno se la diere, e non muere (more) en ella, ca non la debe aver nen muere euna villa ". Por lo que respecta a la prohibición de otros tratos con nobles por parte de los vecinos pecheros sirva también como muestra el citado memorial «El que oviar fidalgo enna villa peche $X$ maravedis, el que dier sua fija o sua parienta por barragana a fijodalgo peche $X$ maravedis. E... qui dier cevada a fijodalgo peche $X$ maravedis", RoDRigUEZ FERNÁNDEZ, J.: LOS Fueros del Reino..., p. 289.

13 Sobre el análisis de un caso concreto de la utilización de un fuero en beneficio del otorgante del mismo, resulta de interés el siguiente articulo: Pérez-Prendes Muñoz-ARRACo, J. M.: «La articulación de los espacios regionales en los reinos hispano-medievales. Propuesta de método y análisis de un caso". en VV.AA.: El Fuero de Santander y su época. Actas del Congreso Conmemorativo de su VIII Centenario, Santander, Diputación Regional de Cantabria, 1989, pp. 11-30. 
De este modo la nobleza jurídica, casi desde su creación está encaminada en primer lugar a la función guerrera y a formar parte del entramado feudal, encaminada por tanto al servicio de los grandes magnates e instituciones feudales. La historiografía ha presentado numerosos textos que evidencian esto para la Alta Edad Media, pero mientras que se han estudiado con profusión las estructuras de poder ciudadanas bajomedievales castellanas y dentro de ellas a la nobleza, sin embargo el estudio de estas otras estructuras de ligazón social y de poder que se conforman alrededor de las grandes casas nobiliarias en esos mismos tiempos bajomedievales necesita de nuevos enfoques y de nuevas profundizaciones que equilibren la balanza historiográfica. Los textos literarios, políticos o no, de la Baja Edad Media en Castilla siguen dando signos de que el noble dedicado a la guerra y al servicio de los magnates era una figura existente y cotidiana. Es más, don Juan Manuel al igual que establece para su tiempo, que por lo común los oficiales de los concejos son pecheros, labradores o no, que «nin biven con los señores ni defienden la tierra por las armas et por sus manos", y al igual que admite que sí hay pecheros en el entramado feudal bajo la figura de los "omnes de criazón», también advierte que los más altos o más delicados oficios se han de dar a los nobles:

Et como quier que los más de los offiçios an estos omnes, pero todos los ofiçios que son tan onrados que pertenesçen para los nobles defensores, tovieron por bien los reys et los señores de gelos dar. Et éstos son así como los adelantamientos et merindades, et en algunos lugares, alcaldías et alguazilabgos, et en sus casas, mayordomadgos, et los pendones et la criança de sus fijos ${ }^{14}$.

$Y$ esto no creo que sea un simple tópico cuando al final del medievo, con las abundantes noticias que aportan los pleitos de hidalguía de la primera mitad del siglo XVI a través de las probanzas de testigos más que de los documentos, se puede observar una quiebra evidente entre los abuelos o bisabuelos de los pleiteantes - generalmente y por ley, los más antiguos en ser referidos- que todavía en alguna manera portan esa condición guerrera y feudal con respecto a los modos de vida de los pleiteantes generalmente insertos en una vida mucho menos militar y mucho más "ciudadana». Evidencias de cambios rotundos que siguen percibiéndose en los comienzos de la modernidad cuando los sistemas feudales y señoriales del Medievo están definitivamente quebrando, la problemática incluso llegará a las Cortes. En las famosas Cortes de Santiago-La Coruña de 1520 entre los capítulos del Reino se recogen dos - Cap. VIII y IX-que apuntan en este sentido: uno de ellos hace referencia a la necesidad de que se paguen las mercedes y salarios y acostamientos de la Casa Real a los hidalgos que le sirven, como hasta entonces se había acostumbrado. En este caso la respuesta regia fue positiva. No tanto en el segundo capítulo que hace referencia a este fenómeno y en donde se sitúa todavía a la Corona como cabeza del entramado feudal, cuando se solicitaba, como antaño se había practicado en Castilla, que se recibiera en la Real Cámara a los hijos de caballeros y nobles de los reinos para educarse y para que con más fideli-

14 Don Juan Manuel: Op. cit., pág. 280. 
dad sirvieran al rey. Esta vez sólo un lacónico "se tendrá en cuenta» demostraba que los tiempos cambiaban ${ }^{15}$. Lo cierto es que no sólo era la Corona la que se iba paulatinamente desembarazando de un armazón feudal cada vez menos útil, sino que también los grandes nobles se despojaban de numerosos servidores de todo tipo, y esto también se observa en las Cortes, concretamente en las de Madrid de 1528 en su capítulo CXXIII:

Otrosi, hazen saber a Vuestra Magestad que muchos grandes de estos reynos han casado y casan sus hijas a quien vienen sus mayoradgos e casan con hijos de otros grandes de estos reynos, e de dos casas prinçipales se hace una sola, porque con el casamiento se consume una de las dichas casas de lo qual viene desenviçio de Vuestra Magestad e mucho danno e perjuiçio a los cavalleros e hijosdalgo e escuderos e a las dueñas e donçellas y otras personas que se acavan en la una de las dichas casas e no tienen donde se puedan criar ni donde le hagan merçedes como se solía e acostunbrava hazer. Suplica a Vuestra Magestad lo mande proveer e remediar como más convenga a su serviçio. A esto vos respondemos que çerca de esto que nos suplicáys tenemos atençión a lo que sobre ello se deva proveer en lo que se ofreçiere de aqui adelante ${ }^{16}$.

Las evidencias de estos cambios, que por otro lado demuestran la práctica anterior, por buena parte de la nobleza, de una vida al servicio de los grandes señores medievales -incluida la Corona- son muchas, sirva de último ejemplo el extracto de esta real provisión del Consejo de Órdenes de 2 de mayo de 1517, en la que la Corona permite que unos hidalgos dedicados por siempre, como los de su familia y linaje, a las armas busquen nuevos señores a quien servir - sin sufrir pena alguna- pues la Corona, a través de una de sus Órdenes, su antiguo señor feudal, ya no estaba interesada en tenerlos por tales:

Por quanto por Juan de Robles e Juan Haznar e Pedro de Balboa e Rodrigo de Xerez e Sebastián Haznar e Diego de Mieses e Sancho Miñarro e Juan Melgares e Lázaro Miravet e Antonio de Robles e Gonzalo Miravet, veçinos de la villa de Caravaca me fue fecha relaçión, por su petiçión que en el mi Consejo de la dicha Orden fue presentada, diziendo que ellos son onbres hijosdalgo y escuderos e ellos e sus antepasados exerçitaron syenpre sus personas en la guerra de los moros y en defensyón de la dicha villa y en serviçio de los reyes nuestros proxenitores e de los maestres de la dicha Orden e que tienen nesçesidad de buscar quién les dé acostamiento para ayuda a sus mantenimientos e que por razón de una ley capitular de la dicha Orden que dispone que los cavalleros y escuderos de ella no bivan con cavalleros de fuera de la dicha Orden se temen que sy les llevan acostamientos e bibiendas de algunos cavalleros de estos reynos que no sean de la dicha Orden les serán pedidas penas e calunyas por el comendador de la dicha villa o por su manpostero por ende que suplicavan e pedian por merçed los mandase resçibir para mi serviçio o les mandase dar liçençia para que puedan bibir con quien quisyeren e mexor para sy se le hizyere en estos dichos reynos o como la my merçed fuese ${ }^{17}$.

${ }^{15}$ Cortes de los Antiguos Reinos de Castilla y León (CCL), Madrid, Real Academia de la Historia, 188..., Tomo IV, pág. 323.

16 idem, pág. 506.

17 AHN, Órdenes Militares, Archivo Histórico de Toledo, Leg. 57.175. 
Pero, lo dicho, la vida al servicio de los señores feudales, tampoco niega y las medidas prohibitivas de los fueros son una evidencia en sí mismas, que la atracción nobiliaria por lo urbano fue una constante, una constante que como es sabido terminó decantándose en favor de los hidalgos y más aún en la Edad Moderna.

Salvo en aquellas localidades, generalmente grandes, en que el acceso de la nobleza a la vecindad no sólo no iba acompañado de la pérdida de sus privilegios sino que además les potenciaba directamente y bajo amparo legal a ocupar puestos de gobierno, es decir a convertirse en verdaderos y prototípicos vecinos ${ }^{18}$, la realidad es que en la mayoría de las poblaciones castellanas el acceso nobiliario, sin perder su condición, a la vecindad y más aún al gobierno local fue el resultado de una larga evolución generalmente conflictiva y que en muchas localidades no termina de dirimirse hasta la implantación efectiva de la mitad de oficios ya en el siglo $x v 1^{19}$.

Estas afirmaciones pudieran parecer, cuando menos, un contrasentido ante una historiografía que presenta ya, aproximadamente entre los siglos XII y XIII, la existencia no sólo de una nobleza urbana poderosa, que lo va a ser aún más a fines del medievo, sino que presenta este fenómeno en todo su conjunto como un hecho comúnmente expandido en toda la Corona de Castilla y que es precedente lógico de la acaparación nobiliaria de los cabildos en la Edad Moderna. No hay tal. A mi juicio el discurso historiográfico, salvo en investigaciones concretas, se ha simplificado en demasía por lo que a esto respecta ${ }^{20}$.

18 Es ésta una concepción muy difundida en la Baja Edad Media y en la Edad Moderna castellana y que sin duda está íntimamente relacionada con afirmaciones como la siguiente de Aristóteles: "De aquí, pues, se colige quién es el ciudadano: porque aquel que tiene derecho y libertad de participar del gobierno, del consejo y de la judicatura se dice ser ciudadano de tal ciudad", ARIStóteles, Política, traducción de Simón Abril de 1584, Barcelona, Ediciones Orbis, 1985, tomo I, pág. 121.

19 Por lo que respecta a lo concerniente a la pugna por alcanzar el poder político concejil de la nobleza castellana me remito a mi tesis doctoral, DIAZ DE LA GUARDIA Y LOPEZ, L.: Litigios de poder en concejos de la Real Chancillería de Granada: pecheros e hidalgos. La mitad de oficios en los siglos XV y XVI, (Tesis doctoral s.p.), UNED, 2005. Tesis que fuera dirigida por el prof. Dr. D. Blas Casado Quintanilla y que se encuentra en fase de publicación.

20 La labor investigadora del prof. Monsalvo Antón por lo que respecta a la historia concejil está fuera de toda duda, no obstante algunos de sus trabajos como MONSALvo ANTón, J. M.: "La participación política de los pecheros en los municipios castellanos de la Baja Edad Media. Aspectos organizativos", Studia Historica. Historia Medieval, VII (1989), pp. 37-94, a mi juicio deben ser revisados, dado que su planteamiento sobre la casi exclusión de los pecheros en la politica concejil -entre otras cosas gracias a los cabildos cerrados de regidores-, que el citado profesor plantea y que les lleva a crear estructuras paralelas para la participación pechera bajomedieval, sólo se puede admitir en muy determinadas grandes localidades y siempre que se tenga por pechero al estrictamente no privilegiado en modo alguno. Pero creo que esa concepción del pechero no se ajusta del todo a la realidad, ya que a mi modo de ver se ha de entender, pechero, más como lo antagónico al noble político que como antagónico al privilegio, pues pecheros eran los alcaldes a los que se les privilegia en muchos de nuestros antiguos fueros durante su mandato y pecheros eran la inmensa mayoría de lo caballeros villanos o cuantiosos que ocupaban las regidurías y que sin embargo gozaban de privilegios por su condición ecuestre. Posiciones como éstas admitidas genéricamente por buena parte de la historiografía - ejemplo evidente de ello es el siguiente libro de conjunto Polo Martín, R.: El régimen municipal de la Corona de Castilla durante el reinado de los Reyes Católicos (Organización, funcionamiento y ámbito de actuación), Madrid, Colex, 1999- dejan fuera de lo establecido historiográficamente a la mayoría de los lugares y villas que estaban todavia en manos pecheras a fines del siglo xv y comienzos del siglo xvı. Esto debe ser subsanado. 
Las prohibiciones forales, ya comentadas y tan reiterativas, sobre el avecindamiento de los hidalgos en las localidades, sin perder su condición de tales pronto debieron ser superadas, no por la evolución del Derecho local castellano, sino por el elemental poder de la oferta y la demanda en la adquisición de bienes raíces, adquisición también generalmente prohibida pero que debió existir desde tiempos muy tempranos. Cierto es que estas adquisiciones contra legem que se fueron consolidando y multiplicando no otorgaban la vecindad jurídica ni sus facultades y cierto es que dieron lugar a una problemática, la de la contribución de las tierras pecheras, que se mantiene, no en la Castilla "profunda" sino por ejemplo en las actuales provincias de Albacete y Murcia, hasta el siglo xv, pero también es cierto que esta presencia como propietarios y residentes de nobles no vecinos en estas localidades, cuando eran varios o incluso numerosos, dio lugar con el tiempo a grupos de presión contra el concejo villano, sus formas de vida y sus normas, dio lugar al llamado estado de los Hijosdalgo de ésta o aquella localidad.

Sin duda estos grupos de presión nobiliarios terminaron accediendo a la vecindad e incluso a la vez al poder político, pero lo que es evidente es que el proceso indica un rechazo primigenio a su consideración de vecinos y por lo tanto a la posibilidad de su acceso al poder urbano. Rechazo que como he puesto de manifiesto en mi reciente tesis doctoral se adentra en muchas localidades pequeñas y medianas del sur del río Tajo hasta el siglo XVI e incluso a inicios del XVII ${ }^{21}$.

Pero si esto ocurrió, el acceso nobiliario al poder local, la evolución que llevó a la nobleza a poder ser vecina y así poder acaparar los cargos públicos concejiles fue muy diversa y aunque resulta difícil de esquematizar se podrian destacar seis modelos:

21. Aunque en mi referida tesis doctoral se abunda en ello y se demuestra lo dicho, sirvan aquí de muestra dos testimonios. El primero pertenece a la villa de Aracena en la que en 1545 se dice por los pecheros: "e de tienpo ynmemorial a esta parte está en uso y costunbre de helegir ofiçiales de alcaldes e regidores e otros ofiçios de conçejo de los veçinos de la dicha villa, que son homes llanos pecheros, y no consentir que sean admitidos a la heleçión de los dichos ofiçios ninguno ome hijodalgo. Antes si algún ome hijodalgo a querydo ser admitido a los dichos ofiçios con los omes llanos pecheros de la dicha villa, a sido allanándose a pechar y contribuyr en los pechos y derramas que los omes llanos pecheros de la dicha villa suelen pechar y contribuyr", ARChG, Pleitos, Caja 4.948, pieza 9. El segundo ocurre más de treinta años después y se refiere al toledano lugar de Polán en 1579, concretamente corresponde al testimonio de su vecino el labrador Francisco Gudino: “a sido uso y costunbre en él que las eleçiones que se an hecho de los dichos ofiçios conthenidos y declarados en la pregunta antes de ésta de este dicho conçejo, de alcalde hordinario y otro de la Hermandad y dos de regidores y de los demás ofiçios, y a sido costunbre para eligirlos, de juntarse una vez cada un año, al principio de él, los ofiçiales que an sido el año precedente a elegir ofiçiales para el año siguiente. $Y$ ansí juntos en las casas de ayuntamiento de este dicho lugar, donde les paresçe de juntarse, y alli an elegido y elixen para ofiçiales del dicho conçejo a los honbres buenos pecheros del dicho lugar en esta manera: para un alcalde ordinario que ay en este dicho lugar se nonbran dos personas, y para dos regidores se nonbran quatro regidores, y para un alcalde de la Hermandad otros dos y para un alguaçil se nonbran ansimismo otras dos personas y por esta horden se nonbran todos los demás ofiçios, los quales dichos nonbramientos, tiniendo respeto que sean ábiles y sufiçientes y que en ellos concurren las caliclades que se requieren para usar los dichos ofiçios, sin entrar en ellos honbres hijosdalgo. Los quales dichos nonbramientos se lleban luego como se haçen las dichas eleçiones al cabildo de la çiudad de Toledo y alli nonbran", ARChG, Probanzas, Caja 9.138. 
a) Localidades en las que desde su nueva estructuración repobladora admiten en su seno a vecinos nobles que además ocupan altos puestos de gobierno.

b) Localidades en las que si originariamente el concejo está en manos de los poderosos locales sin otra calificación que la de villanos, termina el poder municipal siendo asumido por un grupo que surge de los anteriores y que se ha constituido en caballería villana.

c) Localidades en donde por la naturaleza de la población -mayoritaria o absolutamente hidalga - el concejo desde su institución recae en nobles. Se trata de localidades de mediano o pequeño tamaño en zonas de alto o absoluto nivel demográfico de nobles como podrían ser Asturias, Vizcaya, etc.

d) Localidades repobladas con la familia del fuero de Cuenca, en donde ab initio el poder local es asumido por la caballería villana.

e) Localidades en las que independientemente de que en algún momento de su historia ha existido la caballería villana como grupo dominante, superada y abandonada esta práctica y forma de vida, el concejo sigue en manos de los villanos, privilegiados aún o no.

f) Localidades de naturaleza caballeresca en las que los llamados con el tiempo caballeros de linaje -identificados historiográficamente como nobles- asumen puestos de responsabilidad política como vecinos no sólo de pleno derecho sino preeminentes.

Omitiendo las localidades del tipo a y c, sí interesa aquí establecer una sucinta dicotomia entre las restantes: localidades en donde el poder local es un poder caballeresco y localidades en donde este poder es un poder simplemente villano.

Parece, la historiografía lo ha puesto de manifiesto, que en las localidades en donde el poder local estaba en manos de caballeros villanos, de alarde o cuantiosos, la introducción nobiliaria no sólo en la vecindad sino en el mismo núcleo de poder fue pronta y sin demasiados enfrentamientos. Una especie de simbiosis que termina en una fagocitación mayoritariamente aceptada, finca en un ayuntamiento nobiliario donde antes existió un concejo de caballeros villanos. Pudiera parecer que ambas partes salían ganadoras, los nobles dominaban el entramado económico-político municipal y los caballeros villanos, en vez de ser eliminados, son por matrimonios y por autoennoblecimientos, fagocitados por los nobles que los aceptan como tales, siendo el resultado evidentemente un municipio de nobles. Junto a esto y en una tónica similar los ayuntamientos, sobre todo al sur del Tajo, tras la conquista de Toledo en adelante, en donde se admiten como vecinos a los caballeros de linaje terminan fagocitando también a los linajes de poderosos villanos, también caballeros, resultando, todos o casi, admitidos como nobles preferentemente y tras larga evolución en los años fronterizos del siglo xv al xVI. La evolución, además de ser en muchos sitios real parece rotundamente lógica, más cuando en 
el fondo la problemática historiográfica, mencionada o no, se reduce a la siguiente cuestión ¿quién en esos tiempos no querría ser noble? La respuesta: todos querian ser nobles, luego estos procesos se dieron sin grandes fricciones entre caballeros nobles y caballeros villanos. Todos recibian altas compensaciones. Puede ser que en algunas zonas concretas esto ocurriera, pero a mi juicio las fricciones existieron y éstas llegan, por ejemplo, por lo que respecta a los cuantiosos andaluces y del reino de Murcia hasta no ya el siglo xv, sino incluso hasta bien entrado el siglo $\mathrm{XVI}^{22}$.

Debió existir ese anhelo por muchos de ennoblecerse, pero también debió existir el orgullo de pertenecer a familias de caballeros - con toda la carga ideológica que esto encierra-, caballeros villanos que en muchos lugares se sentirian superiores por economías, modos de vida y refinamientos a los nobles residentes en sus localidades que, convertidos o no en Estado, se encontraban al margen de las tomas de decisiones políticas. Pero, independientemente de sentimientos, con seguridad existió una mayoritaria pugna por el poder, tanto económico y social como político, que encerraba cualquier concejo. Y más que el ansia de ennoblecimiento o no, creo que estos argumentos recién mencionados y que se aglutinaban en el poder local debieron producir enfrentamientos a veces muy duros entre los grupos, incluso en aquellas localidades en donde al fin los concejos medievales terminaron siendo concejos de caballeros nobles. Aspecto éste sobre el que aún queda mucho por investigar, desmitificando así evoluciones historiográficas demasiado simples.

Por el contrario, si lo referido ocurrió en muchas localidades de gran o mediano nivel poblacional, existen muchas otras de mediano, pero sobre todo de pequeño tamaño - por cierto, la mayoría de las que conformaban el marco poblacional de la Corona de Castilla - poco atendidas por la historiografía de conjunto en las que la situación evolutiva no fue tan benigna a la nobleza en cuanto a su reconocimiento de vecinos y en cuanto a su acaparación del poder local. En ellas in-

22 Sivan de ejemplo de la oposición de los cuantiosos pecheros a recibir como cogobernantes de sus municipios a los nobles, las siguientes y muy interesantes palabras alegadas, ante la Chancillería de Granada en 1544, por los procuradores de los caballeros de la villa de Cazorla en contra de sus convecinos nobles: "porque a la reypúvlica perteneçe que aya ygualdad en las cosas que tocan al serviçio de Vuestra Alteza y al vien común de todos vuestros súbditos y naturales y sy las partes contrarias (ios hidalgos) quisyesen ygualdad y pechar como todos deven pechar por los bienes que tienen y tener armas y cavallo como los cavalleros de premiá, sería justo que ygualmente gozazen de los ofiçios de la dicha villa, más como esta ygualdad no quieran y pretendan privilegiarse y eximirse de servir a Vuestra Alteza con sus bienes, conviene a la reypública restringir y calificar sus privilegios, pues con esta calidad los ganaron, que dexen los ofiçios a los cavalleros de premiá... Lo otro porque para regir la reypública más se a de consyderar la nobleza del ánimo que el privilegio de no pechar, pues todos los nobles de Derecho Común pechavan, y quien no socorre a las nesçesidades de la reypública no tienen que se quexar que sea escluso de los benefiçios de ella", ARChG, Hidalguía, caja 136, pieza 21. Redundando en esto en la villa de Arjonilla en 1583 se dice: "lo otro porque los ofiçios de conçejo son de los cavalleros quantiosos y no de hijosdalgo. Lo otro porque de tienpo inmemorial a esta parte la dicha villa a estado y está en posesión, derecho, uso y costumbre de que se den y an dado los dichos ofiçios a quantiosos y no a hijos de aigo, ny a los que no son quantiosos ni mantienen armas ny cavailos", ARChG, Hidalguia, Caja 2.076, pieza 9 . 
cluso para fines del medievo se pueden encontrar localidades de poder caballeresco, pero esencialmente villano, o de poder villano simplemente calificado bajo denominaciones como Estado de los Labradores, de los Ciudadanos o de los Hombres Buenos Pecheros, y en las que la pugna, de existir nobles en sus términos suele decantarse siempre o por mucho tiempo en favor de los villanos, salvo que se inmiscuyan en estas lides jurisdicciones superiores. Es más, en contra de las pretendidas afirmaciones aparentemente lógicas que explican el surgimiento del dominio nobiliario en los concejos pequeños o medianos por emulación de un patrón ideal centrado en las grandes localidades, lo cierto es que hasta la implantación generalizada de la mitad de oficios en el siglo XVI en la mayor parte de la Corona de Castilla los núcleos poblacionales, por lo que respecta al poder concejil, estos se encuentran en manos de pecheros, villanos o labriegos, y la pequeña nobleza de estas localidades está apartada del poder concejil y en pugna con él.

Es, pues, la institución nobiliaria castellana una institución jurídica preferentemente conformada por dos realidades de hecho que poseyeron su traducción jurídica y que dieron contenido a la misma: la realidad feudal y la realidad ciudadana.

La anterior sería una explicación imperfecta de la conformación de la nobleza institucional castellana si no nos detuviéramos también en otras dos realidades que le dan su ser: la Reconquista y la Monarquía.

Profundizar en general sobre que la Reconquista -más allá de tópicos y propagandas - condiciona a las instituciones y sociedades castellanas y peninsulares no parece, aquí, oportuno, pero sí testimoniar que como fenómeno de capital importancia fáctica, jurídica y espiritual condiciona a todos y a todo y como es lógico condicionará a la misma nobleza como institución. Siendo quizá unos los efectos más representativos de aquélla en ésta, que el hecho reconquistador y lo a él anejo potenciará en la nobleza tanto su carácter guerrero como su función de servidores de todo tipo al servicio de los entes e instituciones reconquistadoras ${ }^{23}$.

Por último la Corona, la Monarquía, factor ineludible en la confirmación del ser institucional nobiliario y sin el cual no se podría entender. Sobre ella se seguirá inquiriendo y argumentando en este artículo, pero es de notar que la Corona con una clara intención directora del reino, ya desde sus orígenes, es decir, encaminada ineludiblemente a ocupar la cabeza del poder político, pero no de cualquier forma, sino de la manera más absoluta posible, pese a la dura lid a la que durante siglos hubo de hacer frente contra la nobleza, tiene entre sus objetivos ser fuente de creación nobiliaria y fuente configuradora de la misma nobleza. Entendida la nobleza como pilar esencial de la Monarquia, pero también entendida la nobleza como un poder, a veces potencial a veces real, que puede menoscabar las atribuciones de

23 Aspecto que como otros debe ser desgranado con respecto a la nobleza, pues como puso de manifiesto en su dia, Maravall, aunque atendiendo a otros aspectos, «sociológicamente, toda la forma de vida común, y con tal sentido se nos aparece la Reconquista, lleva consigo una tendencia a institucionalizarse, a segregar una normatividad juridica", MARAVALL CASESNOVES, J. A.: El concepto de España en la Edad Media, Madrid, Centro de Estudios Constitucionales, 1997, pág. 281. 
la misma Monarquía y de su titular, ambas cosas empujan a un proyecto de larga duración en que la Corona se perfila o pretende instituirse, en primer lugar, como protectora de la nobleza, lo que junto al discurso político y apaciguador que conlleva, reporta también una intención evidente de establecer una relación de poder con respecto a ella, nadie pudiera ser protector de nadie si no posee mayores capacidades y posición que su protegido ${ }^{24}$.

En esta larga evolución la Monarquia, como es sabido no busca la aniquilación de un pilar que la sustenta, pero sí su sometimiento, sometimiento que, por lo que aquí interesa, se va arrogando por medio de unas funciones no siempre exclusivas de la Corona. Asi la Monarquía castellana pretende ser única fuente creadora de nobleza legal, única fuente legítimamente sancionadora de ella, única instancia reconocedora de su existencia o no, y único poder a la postre que pueda configurar, modificar o incluso extinguir facultades y prohibiciones que son consustanciales a la titularidad de esa misma nobleza jurídica.

Aspectos todos, que en buena parte consiguió, pero por medio de una dificultosa evolución que no llega a su plenitud hasta la Edad Moderna, hasta la configuración del nuevo Estado gracias a la administración política y jurisdiccional en las que tuvieron papel destacado no sólo el Consejo y la Cámara de Castilla, sino quizá aún más las Reales Chancillerías de Valladolid y Granada. Que no fue una victoria absoluta es evidente, pero aunque tardía sí lo suficientemente positiva. Victoria, por cierto, que a su vez consiguió con odres viejos dar nuevos vinos, participando como elemento fundamental en la creación de la nueva nobleza de la Edad Moderna.

Una institución jurídica, la nobleza castellana, afectada por tanto por cuatro realidades fundamentales. Dos de ellas, ciudades y feudalismo que la configuran constante y directamente en grupo o individualmente a través de las vicisitudes existenciales de los nobles. Las otras dos, Reconquista y Monarquía, configuradoras de la nobleza pero desde niveles superiores, a veces de forma indirecta, otras de forma directa, pero mayoritariamente dirigidas sus intervenciones a grandes grupos o a la colectividad nobiliaria en su conjunto. $Y$ a la vez todas ellas $y$, más aún, todas sus intervenciones en o sobre la nobleza, a la postre salvo concretas excepciones poseerán una transcendencia jurídica que dé nuevos elementos a la institución jurídica nobiliaria.

Realidades, las cuatro, en las cuales tiene sentido la nobleza castellana, realidades en las que vive y también con las que pugna y realidades que a través del establecimiento de facultades, deberes y prohibiciones y sobre todo de su práctica,

24 Posición de superioridad protectora que no sólo es propagada por la Monarquía sino también por los señores feudales, al respecto dice don Juan Manuel: "Otrosí, a los fijos dalgo del su enperio deve guardar que ayan sus soldadas comnplidamente et bien paradas, et que estén sienpre guisados de cavallos et de armas et de gentes para su serviçio, et para defendimiento de la tierra et de todo el pueblo en general. Et dévelos amar et presçiar a cada unos segund sus estados, et dévelos mantener en justiçia et en derecho, et guardarles las leys et previlejos et libertades et fueros et buenos usos et buenas costunbres que ovieron de los que fueron ante que ellos», DON JUAN MANUEL: Op. cit., pág. 205. 
la configuran como una institución jurídica de larga pervivencia, pues con un núcleo inmutable pero a la vez un tanto abstracto - la consideración noble de una persona en virtud de la ley- es una institución sin embargo mutable en cuanto a contenidos que rodean a ese núcleo. Mutabilidad geográfica y mutabilidad temporal. Mutabilidad, cambio y sin duda también evolución mejor que decadencia, cuando menos entre los fines del medievo y los primeros siglos de la Edad Moderna. Sobre todo cuando pese al discurso mayoritario es evidente que la función que justifica en último grado a la nobleza de fines del siglo $x v$ y de ya toda la modernidad, más que la función militar en sí, es el servicio y la lealtad al rey, que si antes -mitificadamente se había ejercido por el uso de las armas- ahora se ejerce por medio del servicio político, desde en la más alta Corte hasta en el más humilde lugar y su concejo. Si los nobiliaristas no abandonan la justificación medieval por lo general, otros, entre ellos, sí lo hacen, nobiliaristas como Moreno de Vargas - no sin razón pleiteante en un proceso de mitad de oficios- que escribe en su tratado sobre la nobleza que es el poder político la más alta meta que pueden poseer los hidalgos de su tiempo, pero si esto lo afirman algunos nobiliaristas, los mismos juristas dedicados a escribir sobre las instituciones y la justicia también y con mayor profusión lo propugnan:

Siendo la nobleza ocasión de hazer a los hombres corteses y bien criados, altivos, magnánimos, esforçados, liberales, mensurados, sufridos y leales, enemigos de hazer injuria a nadie... los tales (los nobles) son buenos para cargos y oficios, porque del noble se presume qualquier cosa buena y virtuosa, y que no hará trayción ni agravio a nadie ${ }^{25}$.

Pese al discurso nobiliario moderno y pese a la misma historiografía no se puede reducir la nobleza jurídica al simple privilegio, más cuando la Edad Media castellana está repleta de privilegiados villanos o pecheros, de privilegiados no nobles. $\mathrm{Ni}$ siquiera se puede reducir a la inmunidad tributaria, pues nunca fue ni total ni absoluta para y de los nobles, sino que en distintas circunstancias y por distintos mo-

25 VILladiego-BAsCUCAÑA Y MONTOYA, A. de: Instrucción política y práctica judicial conforme al estilo de los Consejos, Audiencias y Tribunales de esta Corte y otros ordinarios del Reyno, utilísima para los governadores y corregidores y otros juezes ordinarios y de comisión y para los abogados, escribanos, procuradores y litigantes, Madrid, 1617, fol. 92 . Muy lejos y totalmente desterrada quedaba ya la afirmación de don Juan Manuel sobre que la mayoria de los oficios correspondian a los ruanos y labradores, por no ser propios de nobles. Cosa conocida es, en la Edad Moderna, la acaparación por muchos hidalgos de las escribanias de los municipios, pese a ser en principio un oficio tenido por bajo según una larga tradición medieval, cosa ésta que dio lugar a ciertas pugnas aún a inicios del siglo XVI como lo evidencia la siguiente carta de emplazamiento dada en Medina del Campo el 4 de junio de 1518: "Don Carlos por la graçia de Dios, eçetera, a vos el vachiller de Monzón, alcalde mayor en el partido de la Mancha e Ribera de Tajo, salud e graçia. Sepades que Alonso de Ribera en nonbre, como procurador que se mostró, de Rodrigo de Carrión, veçino de la villa de Ocaña, se presentó ante mí en el mi Consejo de la dicha Orden en grado de apelaçión, nulidad e agrabio, en la mejor forma e manera que podía e de Derecho devía, de una sentençia que contra el dicho su parte distes, por la qual declarastes que ningún hidalgo puede tener ofiçio de escrivanía pública de la dicha villa, sino onbre pechero. E me suplicó e pidió por merçed lo mandase rezebir e aver por presentado en qualquiera de los dichos grados e que anulase e revocase la dicha sentençia, le mandase çerca de ello proveer de remedio con justiçia como la mi merçed fuese", AHN, Órdenes Militares, Archivo Histórico de Toledo, Leg. 57.176. 
tivos, muchos pecheros disfrutaron de inmunidades tributarias incluso más pingües que las de los nobles que los circundaban. Repito el núcleo de la institución nobiliaria es ese reconocimiento ex lege de la etérea condición de noble, calidad que inviste a quien es su titular de la presunción jurídica de unas virtudes y cualidades transmitidas por sangre bajo determinados condicionamientos igualmente jurídicos, conjunto de virtudes y cualidades reconocido legalmente que conlleva e implica una serie de facultades y deberes (de hacer o no hacer), facultades y deberes como pueden ser inmunidades tributarias, exclusión o preferencia para ocupar cargos y ejercer determinadas actividades, obligación de acompañar a su rey o señor en la guerra, etc.

Ese núcleo inmutable de la institución que es punto de crítica para los detractores de la condición nobiliaria o incluso para aquéllos que pretenden de forma muy tradicional regenerarla, es precisamente puesto de manifiesto por todos ellos y también por la población en general, cuando se evidencia el común desencuentro entre el conjunto de virtudes y cualidades reconocidas en Derecho, cuando menos como presunción, a una determinada persona o grupo de nobles y el comportamiento real de estos mismos. Esa crítica, independientemente de su fin, sí está dirigida a la esencia de la institución, pues ella es el fundamento de todo lo demás. Críticas que siempre hubo, por ejemplo don Juan Manuel, entre muchos, critica al que se considera sólo noble por su linaje y que con eso era bastante:

Otrosi, les enpesçe (la labor de ciertos educadores de los infantes) mucho porque ellos cuidan et les dan a entender que porque son mucho onrados et de muy alta sangre, que se a de fazer quanto ellos quieren, sin trabajar ellos mucho por ello. Et en esto son engañados, et çierto cred que en mal punto fue nascido el omne que quiso valer más por las obras de su linage que por las suyas ${ }^{26}$.

Pero este tipo de crítica, es una crítica que no busca romper con lo establecido evidentemente, sino que busca su perfección, unir el ser con el deber ser. Cosa distinta es la demoledora crítica de Luis Vives contra la nobleza valenciana o a la nobleza en general, como ocurre en sus Diálogos, que partiendo de presupuestos a veces similares a los medievales, busca la evidencia de la injusticia de la existencia de esos nobles de sangre, de esa nobleza política, que por ejemplo abunda en la Corte:

Casi todos no hacen nada más serio de lo que ves ahora. Por eso la ociosidad es para ellos el padre y la matriz de infinidad de vicios. Algunos juegan al ajedres, a las cartas y a los dados; otros pasan las horas de la tarde en habladurias a escondidas y maledicencias; es el tiempo que pasan en casa; algunos reciben espléndidamente a los bandidos y vagabundos con los que son muy generosos, para las demás cosas se muestran mezquinos y tacaños ${ }^{27}$.

26 Don Juan Manuel: Op. cit, pág. 254.

27 VIVES, J. L.: Diálogos y otros escritos, introducción, traducción y notas de Juan Francisco Alcina, Barcelona, Planeta, 1988, pp. 105-106. 
Luego no han de confundirse las facultades y obligaciones que se desprenden del hecho de ser jurídicamente titular de la nobleza, con la nobleza en sí misma, pese a que es claro que son dignas de profundos estudios y que al historiador le son de gran utilidad para discernir, en sus investigaciones, la nobleza jurídica o no de una persona o grupo.

\section{EL PODER FEUDAL COMO FUENTE DE CREACIÓN DE NOBLEZA POLITICA}

Tres son las fuentes que se pueden presentar como fuentes legítimas de creación de la nobleza política castellana según los tiempos y circunstancias: Sociedad, Monarquía y Poder feudal ${ }^{28}$.

Aunque la Sociedad, más que como fuente legítima se ha entendido por historiadores de la Baja Edad Media y por los modernistas como ilegítima y subrepticia, se olvida que a veces, en Historia, la Sociedad es más soberana que el mismo poder soberano. Además, desde el Derecho no hay duda que la Sociedad es fuente creadora de normas jurídicas, los usos y costumbres que conforman nuestro Derecho consuetudinario tienen su origen último en ella, y, el Medievo, pese al Ordenamiento de Alcalá de 1348, será espacio temporal sobresaliente en el que se desarrolla con importancia este tipo de Derecho, en toda su amplia gama. Sería pecar de ingenuidad histórica si se pensara que esta fuente sancionadora de noblezas no encerrase relaciones de poder en su interior que alejan la gratuidad del reconocimiento de esas mismas hidalguias. Sin llegar al punto de los procesos de hidalguia, en los que también ocurre, pero pleitos que no crean noblezas sino que sólo las reconocen y amparan, y centrados en las fuentes de creación y ahora en la social, es indudable que este reconocimiento no surge como merced sino como conquista de quien lo pretende, que termina activa o pasivamente imponiéndolo al resto de sus convecinos, a la sociedad. Lo cual no resta a ésta su naturaleza de fuente originaria, pues la misma Sociedad ha creado los cauces a través de los cuales se termina generando esa nobleza y lo que es más, una vez asumida esa nobleza será la Sociedad quien la refrende e, incluso, si en las primeras generaciones la discusión sobre

28 La carencia de estudios concretos sobre las fuentes de creación de la nobleza politica y por tanto la falta de bibliografía existente con respecto al tema, me impelen a fundamentarme de nuevo en mi tesis doctoral. Desde el Derecho, desde nuestro Ordenamiento Jurídico histórico resulta muy difícil admitir otra fuente creadora de nobleza política, verdaderamente legitima, que no sea la Monarquía. Pero esto cerraria, a mi juicio, el espectro en tal forma que la explicación de la existencia palpable de otras históricas fuentes creadoras seria muy sesgada y restrictiva, lo que entraría en cofrontación con la profusa actividad de éstas. De ahí que aquí se interprete legitimidad de forma más amplia, basado este concepto en la actividad - durante mucho tiempo no discutida - de estas otras fuentes de creación de hidalguia y en que también durante mucho tiempo los efectos jurídicos de estas otras fuentes de creación distintas a la Monarquia, surtieron sus efectos oportunos que incluso fueron amparados por la Corona. Legitimidades, estas otras, con fecha de caducidad evidente, momento que se plasmará sin remisión con la creación del Estado moderno. El que sancionará definitivamente de Derecho, pero de hecho también, lo que no es menos importante en nuestro discurso, como única fuente legítima de nobleza a la Corona, persiguiendo desde eritonces a cualesquier otras que pretendan serlo o que lo hubiesen sido. 
la calidad hidalga de alguien puede estar presente entre los componentes de esa sociedad, pasadas estas discusiones con los siglos, olvidados los orígenes, no sólo la sociedad refrenda como noble a los primeros poderosos que alcanzaron tal reconocimiento, por lo usual ya olvidados por todos, sino también a sus vástagos de siglos posteriores incluidos los menos afortunados económica y socialmente.

Este ennoblecimiento social posee transcendencia juridica, pues sino no se podría considerar en puridad tal, es decir será un reconocimiento que tendrá su traducción tanto en aspectos fiscales y tributarios, como militares, sociales, etc., pero será también, como ocurre con las otras fuentes de creación de hidalguía, un ennoblecimiento no dado graciosamente, es decir la misma sociedad que lo crea podrá ponerlo en duda, no por la debilidad de la fuente o por búsqueda de purezas sanguíneas, sino como fue usual durante tanto la Edad Media como la Edad Moderna, por intereses socioeconómicos y políticos de todo tipo y de cada momento.

Pero esta fuente creadora de hidalguía, la Sociedad, en puridad, desde lo jurídico, terminará siendo relegada a fuente sancionadora no creadora en cuanto la Monarquía castellana se haga fuerte y los procesos establecidos por ella para determinar la nobleza jurídica de las personas se encuentren claramente tasados y sometidos ya en la Edad Moderna a ambas Chancillerias. Desde ese momento, la Sociedad que sigue creando nobles de hecho, no podrá entenderse fuente creadora legítima de hidalguía pues existe un ordenamiento jurídico que recoge normas que expresamente prohiben esa posibilidad y un Estado decidido, con mejor o peor fortuna, a erigirse en única fuente creadora.

Estado/Monarquía, esa Monarquía que a fines del xv comenzará a instituirse en un Estado moderno, como fuente de nobleza de sangre, sin embargo, siempre fue discutida por amplios sectores de teóricos, fundamentalmente genealogistas y nobiliaristas, contrarios a reconocer una evidencia secular que les repele, entre otras circunstancias, porque el considerar a la Corona como fuente de nobleza es igual a supeditar inexcusablemente a la hidalguía al poder regio. Esta visión incluso es aceptada sin discusión por algunos historiadores hoy en día.

Pero, no todos los tratadistas de épocas pretéritas se decantaron por esta línea de pensamiento, más cuando se implanta claramente, gracias al Renacimiento y, en la Península, gracias sobre todo a la Recepción del Derecho Común, la división ya mencionada que delimitaba cuando menos tres tipos de noblezas. Existiendo, en consecuencia, una nobleza política o civil, esa nobleza procede sin remisión del poder estatal que en estos escritos viene a ser representado por el Imperio romano, por la Monarquia visigoda y al fin por los reyes peninsulares y en nuestro caso por la Monarquía castellana ${ }^{29}$.

29 Sobre esto me remito al siguiente artículo, DIAZ DE LA GUARDIA Y LOPEZ, L.: «El deber de fidelidad al Rey como justificación de hidalguía en la nobleza de España e Indias", Anuario Mexicano de Historia del Derecho, XV (2003), pp. 103-168, y concretamente y como ejemplo de esta división nobiliaria, aceptada y propagada, me remito al manuscrito 9.645 de la Biblioteca Nacional, transcrito en el mencionado articulo en la pág. 116, documento datado en 1592 y cuyo autor fue el deán de Astorga don Antonio Quintela Salazar. 
Sin duda la incipiente Monarquía astur, en los inicios de la Reconquista, tuvo que aceptar noblezas preexistentes a ella, pero sin duda, también, lo que terminaría siendo la Monarquía castellano-leonesa hubo de configurar una nueva nobleza - recogiendo en su seno la anterior - tanto en cuanto a sus componentes como a usos, privilegios y obligaciones. $Y$ en esa conformación de la nobleza en todos sus estratos posibles, y muchos desconocidos, la Monarquía hubo de representar un papel destacado como fuente de creación. Fuente de creación tanto expresa como tácita. Creación expresa, por medio de mercedes que taumatúrgicamente crearan noble al villano, y creación tácita, al conceder oficios y empleos que reportaban la condición nobiliaria a quien los ostentaba, o, también tácita, al reconocer por la simple cotidianeidad como nobles e hidalgos frente a terceros a cercanos a la real persona.

La creación expresa, siempre que se haya conservado el privilegio, es la más notoria, la que puede ser objetivizada por el historiador con mayor precisión. Pero, igualmente, las otras dos hubieron de existir y deberían ser en su momento analizadas y rastreadas, pues en ellas también estará el origen de muchas importantes familias.

En cualquiera de sus formas, la Monarquía como fuente creadora de nobleza, en principio, debería y debió ser la más fuerte, eficaz y segura de ellas, lo que en ningún momento impidió su contestación y no sólo en etapas de debilidad regia sino incluso en fases en que la Monarquia gozaba de salud indiscutible ${ }^{30}$.

Apuntadas quedan dos de las fuentes de creación de la nobleza política, seguir su desarrollo sería muy largo y complicado y se deja para otros trabajos, pues lo que interesa aquí es evidenciar la existencia de una tercera fuente: el Poder feudal.

30 De que la Corona no sólo recibía contestación a sus ennoblecimientos y a sus actuaciones sobre la nobleza en momentos de debilidad, sino que también y con determinación era contestada en épocas de fortaleza, es muestra la consulta del viernes 11 de enero de 1577, elevada por los señores Fuenmayor, Juan Tomás, Liébana, Covarrubias y don Lope, en la que se refiere que "Juan Gelder, vezino de Almagro, natural de Subia en el ynperio de Alemania, puso demanda con testimonio de prenda al conçejo de Almagro ante los alcaldes de Hijosdalgo de Granada, pidiendo que le declarasen por hijodalgo en posesión e propiedad. $Y$ abiéndose puesto exçeçiones y substançiado el pleyto con el fiscal y conçejo, se hizo una provança por testigos por Joan Xelder y asimismo se presentó un previlegio de Su Magestad, por el qual refiriendo Su Magestad que por ser tan lexos la provança de Suabia no podía averiguar su nobleça ni haçer la provança que vastase para provar su hidalguia, que to haze hijodalgo notorio de sangre y solar conosçido de bengar quinientos sueldos según fuero de España y a todos sus desçendientes legítimos, con muchas cláusulas favorables derogando todas las leyes que de esto hablan y espeçialmente le conçede que quando quisiere poner demanda de su hidalguía, él o sus desçendientes, los alcaldes de los Hijosdalgo y Audiençia donde la pusiere le pronunçien por hijodalgo de sangre y no de previllegio y que el fiscal no ynsista en el negoçio y que los alcaldes de los Hijosdalgo y el presidente y oydores den executoria de las sentençias sin haçer minçión ni relaçión ni declaraçión en ella que se da por virtud de esta carta de previlegio y sin poner treslado de ella en la executoria como sy en el pleyto no huviera sydo presentada y como si huviera dado la executoria abyendo preçedido bastante provança y que solamente se ponga en la executoria lo que el Juan Gelder quisiere. Y que el fiscal sobre esto si quisere pedir algo no sea oydo y ynibe todos los jueçes para que no proçedan en esto, no enbargante las leyes que disponen que las cartas que contienen semejantes clásulas sean ovedeçidas y no cunplidas y finalmente dize que solamente sean jueçes de este pleito los alcaldes de los Hijosdalgo y notarios como lo son en las otras ydalguías de sangre. Ynibe los demás jueçes. Estando concluso el pleyto en Granada los alcaldes de los Hijosdalgo ynbiaron al Consejo una relaçión del estado del pleyto y del previlegio, juntamente con el proçeso, diziendo que este previlegio hera muy perjudiçial al estado de los Hijosdalgo», AHN, Consejos, Leg. 7.044. 
Mientras que, sin ahondar demasiado y a veces con discutibles apreciaciones, la historiografía ha reparado en las dos primeras fuentes de creación de nobleza aqui comentadas, resulta sorprendente que no se haya hecho hincapié, en esta tercera vía, en esta tercera fuente de hidalguía. Se entiende al poder feudal como fuente de hidalguía no en beneficio de quien es el titular de ese poder sino en beneficio de aquéllos que estaban al servicio de ese mismo poder. Es de suponer que el titular del poder feudal o ya es noble o por sus propios medios será reconocido como tal, lo que entraría, más, dentro del prototipo de la Sociedad como la fuente de creación que dentro del mismo Poder feudal entendido en igual sentido. Más, cuando aquí la adquisición de la nobleza jurídica se considera fundamentada en último extremo en una relación desigual de poderes.

Es una evidencia demostrada para la Alta Edad Media que el Poder feudal fue fuente ennoblecedora de sus servidores, principalmente de sus servidores dedicados a la guerra como caballeros, los llamados milites. Pero también es evidente que por parte de la historiografía y por lo que respecta a la Baja Edad Media se ha descuidado el estudio de una actividad que seguía vigente como era la fuente de creación de nobleza política que continuaba encarnando el Poder feudal en estos siglos.

Para la Baja Edad Media, en principio, parece escapar a las competencias y capacidad de cualquier señor feudal castellano la facultad de ennoblecer expresamente a sus servidores e individuos de su casa. Pero también es notable que el poder feudal no sólo se fundamenta en unos pretendidos servicios recíprocos entre la cabeza y los miembros del entramado feudal, sino que él mismo es fuente de mercedes y privilegios para terceros.

Según nuestra tradición jurídica correspondería en exclusiva a un poder soberano la facultad de crear nuevos nobles, y parece evidente que nuestros poderes feudales no alcanzaron jurídicamente esa condición y por tanto tampoco poseyeron ex lege semejante facultad. Pero cabe preguntarse si en circunstancias en que el poder regio estaba en crisis, muy cuestionado o debilitado, los titulares del poder feudal, al igual que asumieron otras competencias en principio propias de la Corona, no asumieron ésta también, la facultad de declarar y privilegiar a un individuo como noble.

Es conocido que el Poder feudal castellano consiguió para sus servidores y criados más afortunados la concesión regia de todo tipo de mercedes y honores, y entre ellas el ennoblecimiento, pero en este caso la fuente de creación de la hidalguía, pese a que la iniciativa parte del Poder feudal, sería la Corona y no un determinado magnate, no el Poder feudal.

A mi juicio la naturaleza creadora de hidalguía del Poder feudal debió, comúnmente, optar por otras vías, sin descartar la concesión por escrito de cartas de hidalguía en las que se creaba esa nueva nobleza. De hecho la carta de hidalguía del marqués de Villena a continuación analizada roza esta última circunstancia. 
El Poder feudal gustó de rodearse de servidores, criados y vasallos nobles, independientemente de si pertenecían a su grupo familiar o no. La ideología ya asentada en el siglo XIII castellano lo recomienda, pues los considera a estos nobles más dignos para servir a los magnates y más seguros que otros en virtud de esas cualidades que, como presunción, son el núcleo de la hidalguia, de la nobleza jurídica.

$Y$, como se ha referido, el titular del Poder feudal posee como pago a los servicios destacados de sus servidores y también como instrumento al servicio de su política, múltiples fórmulas recompensatorias: nombramientos de cargos y oficios en sus dominios y casa; acostamientos; armar caballeros - pese a que hubiera discusión doctrinal de si en Castilla con respecto a Derecho pudieran hacerlo-; enlazar a sus criados con linajes de nobleza y cuantías acrisoladas; crear excusados; etc. ${ }^{31}$.

De hecho esta última cuestión de los excusados fue fuente de debate probatorio en muchos pleitos de hidalguía, pues el origen de muchas noblezas se debió fundamentar en apariencias de tales, por ejemplo al demostrar que no habían pechado y que esta circunstancia, olvidadas mayoritariamente las causas, no estaba fundamentada en el privilegio de un determinado señor que lo había excusado, sino en el propio origen nobiliario del exento.

No obstante, en esta circunstancia no existe una voluntad creadora de nobleza por parte del Poder feudal, sino que es pretexto utilizado por parte de un determinado noble para que la sociedad lo tenga por tal o para que la jurisdicción reconozca su nobleza. Pero, al igual que en este caso podía no existir esa voluntad feudal de creación de nuevas noblezas, en donde sin duda la hubo, fue en aquellas circunstancias, expresamente provocadas por el titular del Poder feudal, para que una persona o familia fuera tenida por noble en atención a la propia actitud de reconocimiento de tal por parte del señor feudal.

Resulta difícil de creer que cuando un determinado magnate comenzara deliberadamente a tratar ante los demás de su casa a un individuo como noble, por las circunstancias que fueran, pero en cualquier caso para honrarle y hacerle merced, alguien se atreviera abiertamente en esa casa e incluso en sus dominios, en caso de un fuerte Poder feudal, a negar la nobleza del agraciado. La reiteración temporal

31 La práctica de crear excusados aún se rastrea en el siglo XVI, como lo demuestra la siguiente consulta de 13 de noviembre de 1592: «El síndico de la villa de Morón suplica se dé provisión para que el duque de Osuna no dé libertades ni exsençiones a persona alguna que vaya a bivir a la dicha villa de Morón para que no les hechen huéspedes ni cobranzas de bulas ni curadurías ni otras cosas. Mandose que el dicho duque ynformase. El qual ynforma y dize que es verdad que él a dado las dichas çédulas de exsençión a algunos de sus vasallos y que en esto no a hecho novedad alguna, más de llevar adelante la costumbre y posesión que para haçer esto tiene de sus padres y abuelos de tienpo ynmemorial a esta parte. Los quales sienpre an dado las dichas exsençiones como constará por provisiones y escripturas antiguas que protesta presentar en su tienpo y lugar siendo nesçesario y que pide traslado de la dicha provisión para responder más en forma". No obstante se le prohibió al duque semejante práctica medieval en esta ocasión, AHN, Consejos, Leg. 7.052. 
de esos reconocimientos no ya en el agraciado sino también en su familia, podían y pudieron perfectamente acallar el origen de la nobleza y los comentarios adversos a ella, que si no abiertamente sin duda bajo la prudencia se harian, y acallado origen y comentarios e incluso olvidados, perfeccionar esa nobleza cuyo origen deliberado estaba en la acción del Poder feudal ${ }^{32}$.

Actitud, acción, pero también existencia, muy posible, de patentes y documentos dirigidos a terceros en donde el señor feudal, pese a ser consciente de que la nobleza de su vasallo era creada por él mismo, ordenaba a todos los suyos y villas el tener por noble sin discusión al agraciado en virtud de la afirmación señorial. Es ésta una práctica que aún se puede testimoniar a fines del medievo e incluso en el siglo XVı llevada a cabo por concejos y reyes, con diversos resultados, claro está.

En cualquier caso es ésta una fuente de creación de hidalguía limitada. Limitada por razón de su origen en dos sentidos: territorial y en relación del efectivo poder del señor feudal.

Mientras que la Monarquía y la Sociedad como fuentes de creación de hidalguía no poseen limitación territorial alguna, por lo menos de inicio, siendo único límite territorial, en principio, las fronteras del reino, por el contrario la parcelación del Poder feudal en multitud de titularidades impide una universalidad territorial $a b$ initio del ennoblecimiento, sea cual sea el cauce elegido, de un vasallo.

La hidalguía que posee como fuente de creación el Poder feudal, necesariamente, estará condicionada en cuanto a su aceptación como nobleza jurídica y, por consiguiente, también el ejercicio de las facultades y deberes que de ella se derivan, a los territorios en donde el señor feudal que la ha creado ejerce su dominio. Más allá, siempre resultará menor la validez del ennobleci-

32 Esta fúrmula de ennoblecimiento, basada en la actitud deliberada y cotidiana del Poder feudal en beneficio de un servidor suyo, debió ser habitual cuando entre las preceptivas preguntas de los interrogatorios de las probanzas de los procesos de hidalguía siempre se inquiere sobre si la apariencia de nobleza está fundamentada en una verdadera nobleza o en el amparo que un señor poderoso, caballero, alcaide, etc. Esta pregunta a veces sirvió o bien para desenmascarar verdades o para enturbiarlas, y esto último cuando los testigos presentados por la parte enemiga al que pretendía el amparo de su nobleza, aunque ésta fuere cierta, recordaban los lazos del actor o de sus pasados con grandes señores, a veces achacando abiertamente sus encumbramientos simplemente a esas relaciones. Lo sufren, entre muchos y por ejemplo, los Arias de Don Benito a inicios del siglo xvi cuando se afirma en un alegato fiscal lo siguiente: «por la provança presentada por parte del dicho conçejo paresçia e se provava que la libertad que avia tenydo el dicho Miguel Arias e tovieron Fernán Garçia Arias, su padre, e Arias Gómez, su agüelo, de no pechar ni contibuyr avía seydo por ser cavalleros del conde de Medellín e por ser favoresçidos de él» ARChG, Registro del Sello, Caja 5.531; también lo padecen los Cavezalbo-Conde, de Cáceres, en 1579, cuando a los testigos del fiscal y del concejo de Cáceres se les pregunta: "Si saben que el dicho Hernando Conde, padre de los litigantes, se fue del lugar de Xarayz a la dicha villa de Cáçeres, soltero por casar, en serviçio de Juan de Sande Caravajal, el qual fue un cavallero muy prinçipal, enparentado con los mejores y más prinçipales cavalleros de la dicha villa y favoreçido en Conte y Consejo de Su Magestad y Corte Romana, porque tuvo por hermano al cardenal de Santa Cruz, de tal manera que en la dicha villa y conçejo de ella no se hazía otra cosa más de lo que él quería y mandava", ARChG, Probanzas, Caja 9.135. La actividad estatal de la Monarquia en este sentido demuestra la existencia de estas prácticas ennoblecedoras pero también avala que una Monarquia fuerte perseguía con reiteración hábitos medievales que no podían ser consentidos en un Estado moderno. 
miento o incluso nula. Cosa distinta es que tras el primigenio ennoblecimiento feudal, diversas generaciones se hayan mantenido en posesión de su nobleza en forma tal que ésta goce de la categoria de inmemorial, con lo que como cualquier otra nobleza podrá exigirse a terceros en cualquier parte del reino su salvaguarda, habiéndose ya olvidado su origen.

De igual modo a la situación relatada con respecto a la Monarquía, pero con importantes matizaciones que ahora se verán, la efectividad del Poder feudal como fuente de creación de hidalguía depende en grado sumo del verdadero poder que el titular pueda ejercer sobre sus dominios y dependerá también de la capacidad de contestación a sus decisiones que puedan desarrollar concejos y otros vasallos de los cuales es señor. Son conocidas las muchas protestas concejiles que por ejemplo -en el terreno de los privilegios-se dieron contra sus señores naturales para hacer frente al incremento o creación de excusados, como es evidente la existencia de concordias entre señores y concejos que responden a momentos de debilidad del poder señorial en que éste es incapaz de, omnímodamente, imponer sus designios. El Poder feudal como fuente de hidalguía, no deja de ser una fuente en precario, dado que nunca llegó a poseer de Derecho esa capacidad, sino que la ejerció de hecho o rozando quizá una pretendida legalidad nunca alcanzada, aunque tampoco se puede dudar que independientemente de su legitimidad, su creación podía ser perfecta a la hora de generar efectos jurídicos y de crear una auténtica nobleza institucional ${ }^{33}$.

El no poseer, desde un punto de vista jurídico, entera o incluso alguna legitimidad creadora de hidalguía impide su plasmación efectiva en casos de rotunda oposición por parte de la sociedad que ha de asumir en su seno un nuevo noble y que la debilidad de un poder feudal determinado se ve incapaz de vencer. Ocurre de igual forma con la Monarquía, es cierto, pero mientras que ésta, en teoría libremente, no revoque la merced, el privilegio de hidalguía seguirá vigente, será en Derecho indiferente el que los terceros obligados a acatar a un nuevo noble, obe-

33 La actividad en contra de los excusados es de por sí muy antigua, pese a los también antiguos preceptos forales que, entre otros, los amparaban, pero la multiplicación de los exentos podia llegar a ser insufrible para los concejos. De este modo y en este sentido, el 25 de julio de 1407, ante los alcaldes ordinarios del lugar de Santa María de los Llanos, compareció Andrés Martínez Donoso, en nombre de la villa de Belmonte, para solicitar un traslado de una carta de Enrique Ill y que pensaba utilizar el concejo de Belmonte en su favor, pues éste sabía que un ejemplar se guardaba en Santa María de los Llanos, carta que según el procurador contenia una ley del Soberano en la «que mandava que pecharen todos los escusados e los que se escusavan de pechar en todos los pechos asy reales como conçejales e que mandava por ella que fuese publicada por todos sus regnos", AHN, Consejos, Leg. 28.345. La actividad en este sentido de la villa de Belmonte fue eficaz, como lo demuestra el que cuando el marqués de $\mathrm{Vi}$ llena excusó en esa localidad a su vasallo Juan de la Peña en 11 de febrero de 1476, tuvo que hacerlo de una manera singular -soportando el marqués las consecuencias económicas-, fórmula que ya era tradicional en este señor y en Belmonte con el fin de no enfrentarse al concejo: " $Y$ por quanto esa dicha mi villa tiene previlegio que todos los que tuvieren bienes pechen y contribuyan por ellos y porque mi voluntad y querer es que el dicho previlegio se guarde, por esta carta vos mando que de qualesquier maravedís que oviéredes a dar en cada un año, ansy de serviçio como en otra qualquier manera vos entreguedes y tomedes los maravedis que al dicho Juan de la Peña y a sus bienes le copiere a pagar de los dichos repartimientos y derramas, cargando según que a otros mis criados que de mí tienen semejantes merçedes", AHN, Consejos, Leg. 28.344. 
dezcan pero no cumplan. E incluso, aunque por un sector de la doctrina de los siglos XVI y XVII se pretendió que el no uso continuado del privilegio hacía prescribir sus efectos y validez, estas circunstancias no fueron tenidas en cuenta por jueces y tribunales de las Chancillerías que en su doctrina jurisdiccional reiterada no asumen la prescripción del privilegio por su no uso. No era indiferente esta situación, claro está, para quien quería gozar de su nueva condición, el que generalmente, como demuestra la documentación, buscaba los caminos políticos pero también jurisdiccionales más útiles para que su titularidad, su propiedad o posesión de la nobleza institucional, le fuera reconocida, unas veces con resultado positivo, pero a veces también negativo.

Se debe recordar aquí, que incluso las mercedes de hidalguía derogadas, ejemplo importante son las dadas y después derogadas por Enrique IV, pudieron recuperar su efectividad y validez ya con los Reyes Católicos bajo el cumplimiento de ciertas condiciones impuestas por estos últimos, y que incluso las no perfeccionadas así y que estaban y permanecian derogadas fueron aceptadas como fuente de hidalguía por las Chancillerías, y es de suponer que por los tribunales inferiores que pese a no ser competentes entendieron de estas materias, lo que dio lugar a iniciativas legislativas de la Monarquía, que arrancan ya con los Reyes Católicos con la Pragmática de Córdoba y que continúan hasta el gobierno del Emperador.

\section{EL PODER FEUDAL COMO FUENTE DE HIDALGUIA: UN EJEMPLO BAJOMEDIEVAL DEL MARQUESADO DE VILLENA}

El caso que se trae aquí a colación como ejemplo de la actuación del Poder feudal como fuente de creación de hidalguía, de nobleza política, es un caso prototípicamente bajomedieval castellano en relación al análisis que se hace en estas páginas, sobre todo por la conjunción de diferentes influencias ya tratadas y que en él se entrecruzan.

Juan de la Peña, vecino del entonces lugar de Montalbanejo, de la jurisdicción de la villa de Alarcón, hoy en la provincia de Cuenca, era fiel y eficaz servidor de los Pacheco, marqueses de Villena, y especialmente lo fue de don Diego López Pacheco, su verdadero hacedor. Su actividad política y militar como vasallo de López Pacheco será pronto recompensada en cuanto éste alcance la titularidad del marquesado de Villena, tanto por su señor como por el Monarca castellano.

Posiblemente perteneciera por vía femenina al linaje hidalgo de los De la Peña de esta zona del marquesado de Villena y cuyos descendientes también radicaban entre otros lugares y villas en el lugar de Montalbanejo, sin embargo su calidad era pechera - de ahí la suposición del entronque por vía femenina con los hidalgos de igual apellido- y como caballero villano serviria a sus señores feudales en varias e importantes acciones tanto de las guerras del reinado de Enrique IV en general, como, más concretamente, en las distintas campañas que enfrentaron a 
Pachecos y Fajardos, en el marquesado de Villena y en esa zona del levante peninsular. Su condición privilegiada como directo servidor de tan importante señor auguraba grandes ascensos sociales y políticos, como los tuvo, pero ascensos que salvo que cambiase de calidad tendrían siempre un límite insuperable que jurídica y socialmente le incapacitaba para todo aquello que estuviese vedado a los villanos.

Don Diego López Pacheco decidió apoyar a su vasallo, sirviéndose de su ascendencia sobre el rey Enrique y aprovechando la liberalidad del monarca a la hora de conceder todo tipo de privilegios a sus servidores, consiguió para Juan de la Peña privilegio de hidalguía que como era usual lo elevaba por la merced a la condición de hidalgo notorio de solar conocido, condición que comportaba gozar de todas las facultades y obligaciones reservadas a los demás hijosdalgos de Castilla. Nobleza que no sólo adquiría Juan de la Peña, sino que, como también es frecuente, era extensiva para siempre jamás en sus hijos e hijas, habidos y por haber $y$ en todos los que de él y de ellos viniesen y descendiesen.

Los merecimientos de Juan de la Peña seguirían aumentando ante la facción de don Diego López Pacheco, merecimientos que estaban ahora claramente fundamentados en el ejercicio militar a su servicio y al del rey Enrique. Diversas campañas en el marquesado contra los Fajardo lo acreditaban como buen guerrero, en tal forma que siendo comendador de Socovos, el tío de Pacheco, Alonso de Lisón, éste armaría caballero en el fragor del combate a Juan de la Peña, en la toma de la fortaleza de Mira:

El dicho Alfonso de Lisón, mi capitán susodicho, armó cavallero al dicho Juan de la Peña dentro de la cava de la dicha fortaleza (de Mira), pendiente el conbate que en la dicha fortaleza e castillo se dio, por muchas cosas que él ende fizo e se portó muy bien como cavallero ${ }^{34}$.

Como resulta evidente por lo que relata el documento, en primer lugar consta como fuente creadora de hidalguía la Monarquía y no el Poder feudal: es Enrique IV el que crea un nuevo hidalgo de sangre de solar conocido de vengar quinientos sueldos a fuero de España. La actividad del Poder feudal se limita, en esa relación de poder que encierra el otorgamiento del privilegio, a sugerir, a presionar, a solicitar con efectividad a la Corona que eleve al rango de la nobleza jurídica a uno de sus servidores que ha acreditado poseer en si esas virtudes, esa nobleza interior, que le hacen merecedor del acceso a la nobleza jurídica.

La razón de este hecho se debe a varias razones, que se resumen en una: la legitimidad indiscutible que ante los ojos de todos ha alcanzado, en la Baja Edad Media castellana, la Monarquía como única fuente creadora e inatacable de hidalguia, de nobleza jurídica.

34 AHN, Consejos, Leg. 28.344. Dado que el resto de las citas documentales corresponde al mismo legajo y documento, obvio a partir de ésta cualquier nueva referencia al mismo. 
El marqués de Villena podría haber optado por el ennoblecimiento de hecho de su vasallo y la imposición de su aceptación a través del entramado feudal del que era cabeza, pero prefiere optar por la legitimidad asumida de la Monarquía y utilizar su ascendencia sobre el soberano para que éste sea fuente creadora indiscutible de la nueva hidalguía. La legitimidad de la fuente y el apoyo del poder de los Pacheco harían la merced decididamente efectiva.

Esto no impide ni niega que el Poder feudal y lo que comporta, en la Baja Edad Media castellana, casi a su fin, siga siendo fuente creadora de privilegios, aún sin legitimidad o con legitimidad discutible: en la carta de confirmación dada en favor de Juan de la Peña por Enrique IV en Segovia el 16 de octubre de 1470 queda constancia de ello. La verdadera orden de la caballería recibida por el antiguo caballero villano y ya parece que hidalgo, de manos de Alonso de Lisón, es una caballería imperfecta en Derecho, en tanto en cuanto que pese a ser caballero de Santiago y comendador el citado Lisón, éste no tenía poder bastante para conforme a ley armar ningún caballero, aunque sin duda era una práctica común todavía en la Baja Edad Media castellana y que se debía remontar a pasados remotos y de la que sigue haciendo uso todo el entramado feudal en el siglo $x v$. Caballerías que además, con seguridad, poseian efectos jurídicos como si fueran enteramente válidas y que privilegiaban, aunque no ennoblecían, al beneficiario y a sus descendientes. Sin duda ese cometido y finalidad -efectividad jurídica del acto de haber sido armado caballero- lo poseía el testimonio signado de escribano dado en su momento por Alonso de Lisón en favor de Juan de la Peña y que el último presentó ante el rey Enrique, para que éste lo convalidara cuando asumió la posibilidad de su no cumplimiento y acatamiento por parte del lugar de Montalbanejo:

E que después, él, estando en mi serviçio con don Diego López Pacheco, marqués de Villena, sobre el castillo e fortaleza de Mira, que Alfonso de Lisón, comendador de Socovos, capitán de la que gente que por mi mandado estaban en el çerco del dicho castillo e fortaleza, le ovo armado cavallero. Lo qual paresçió ante mí por un testimonio firmado del dicho Alonso de Lisón, mi capitán, e signado de escrivano público.

Poder feudal bajomedieval castellano que es fuente creadora de privilegios pero que parece no ser ya fuente creadora de nobleza, función que ha dejado definitivamente en la potestad regia ${ }^{35}$. No obstante, el último fin de cualquier fuente creadora no es ya crear sino que su creación posea vida y existencia real y esto último depende en grado sumo de la misma fortaleza del ente creador. Enrique IV fue como titular de la Corona un fructífero creador de nuevas noblezas, pero como se ha dicho y es conocido, también se vio obligado a revocar sus creaciones en la mayoría de los casos, aunque después volvieran a ser puestas en valor por los Reyes Católicos algunas de ellas o aunque, incluso las que permanecieron

35 Ejemplo de esta continuidad como fuente emanadora de privilegios es el documento también relativo a Juan de la Peña y que se contiene en el apéndice documental bajo el número segundo. 
revocadas, fueran admitidas como arregladas a Derecho por jurisdicciones que actuaron con poca pulcritud o diligencia, o aunque incluso fueran validadas a través de los hechos y los tiempos gracias a la habilidad de los mismos concesionarios o de sus descendientes. Pero lo que es un hecho es que sus creaciones de nuevos nobles, casi en masa, recibieron fuerte oposición por sus contrarios, al fin vencedores, e incluso por cualesquier ciudades y lugares aunque fueran fieles al desdichado Enrique IV, lo que le obligó a las citadas revocaciones.

Esta debilidad de la Monarquía, llevó a Juan de la Peña a buscar nuevas confirmaciones, más ante las revocaciones regias de hidalguía y ante la presumible oposición por parte del concejo de Montalbanejo, donde era vecino, a acatar no sólo el privilegio de nobleza sino incluso su imperfecta caballería. El apoyo de $\mathrm{Pa}$ checo y la voluntad regia dieron lugar a que Juan de la Peña viera no sólo confirmada y vuelta a perfeccionar su hidalguía sino también su caballería por carta de confirmación dada en Segovia por el rey en 1470:

E que entendiendo que lo que él fizo por entonçes cabía bien en él la horden e dignidad de la cavallería por aver exerçitado muchas vezes los abtos melitares de ella, según que fue mostrado ante mí e paresçió por el dicho testimonio. $E$ dize que se reçela que vos o alguno de vos non la queredes guardar a él e a sus fijos e a los deçendientes de él y de ellos la dicha mi carta de fidalguía e la dicha cavallería, diziendo que non deve gozar de ellos porque yo mandé rebocar todas las cartas de fidalguías que por mí fueron dadas de zierto tienpo acá, e ansymismo porque el dicho Juan de la Peña no fue armado cavallero por mí ni por persona que para ello poder tuviese... le apruebo e afirmo e confirmo al dicho Juan de la Peña la dicha cavallería e lo he por cavallero... así e como sy por mi mano propia fuese armado cavallero, ca por la presente le afirmo e confirmo al dicho Juan de la Peña e le apruevo la dicha cavallería que el dicho comendador Alfonso de Lisón lo armó como de suso es dicho. E quiero y es mi merçed e voluntad que aya tanta fuerça e vigor e efecto como sy le yo oviere armado cavallero en mi Cámara o en guerra, guerreada contra moros e otras gentes de fuera de mis reinos, con las solenidades de las leyes de los dichos mis reynos quieren y mandan.

De nada sivieron ni sus gestiones ante el Monarca ni el poderío y potestad real absoluta de Enrique IV, el concejo de Montalbanejo, lugar de la villa de Alarcón, en el marquesado de Viliena, y que durante un tiempo aceptó y cumplió las originarias concesiones, negó la validez incluso de la confirmación segoviana de 1470:

La qual le guardastes çierto tienpo (la hidalguía y caballería) según que ante mí paresçió, e de poco tienpo acá le prendastes por el pecho e vos requirió que le tornásedes la dicha su prenda, que ansy ynjustamente le aviades fecho. Lo qual no quisystes hazer.

Estas últimas palabras no corresponden ya al rey Enrique IV, sino a don Diego López Pacheco, marqués de Villena. Y aqui de nuevo el Poder feudal se hace protagonista principal tanto como fuente creadora de hidalguía como jurisdicción competente para conocer un caso de Corte. 
Hacía tiempo que los pleitos de hidalguía eran casos de Corte que correspondían en exclusiva a la audiencia regia, pero competencia discutida hasta la implantación decidida y fuerte de las Chancillerías ya en el siglo XVI, pues concejos y otras jurisdicciones siguieron entendiendo de estas causas en virtud de costumbres más o menos inmemoriales. Juan de la Peña, avasallado en la titularidad de su hidalguía y ante la debilidad regia, buscó amparo en su señor y recurrió ante su jurisdicción, actitud fundamentada tambien en que posiblemente sospechara que de dirigirse ante los alcaldes de los Hijosdalgo del rey, la jurisdicción verdaderamente competente, éstos, cumpliendo la voluntad de las Cortes y de las revocaciones, le dieran por pechero.

El marqués, como señor jurisdiccional y también feudal, se declaró capaz para entender en la protección de la nobleza de su vasallo. No obstante su intervención no fue inicialmente directa y rotunda. Optó por la vía jurisdiccional y, aunque desde un primer momento reconoció la legitimidad de la nobleza de De la Peña, accedió a oír a la otra parte, al concejo de Montalbanejo:

Sobre lo qual el dicho Juan de la Peña paresçió ante mi e se me querelló de lo susodicho, sobre lo qual yo mandé dar mi carta para vos el dicho conçejo, para que luego diésedes e restituyésedes la dicha prenda al dicho Juan de la Peña, o que sy alguna razón teníades para vos para lo no dever asy fazer e cunplir, que dentro de nueve dias después que vos fuese notificada, paresçiésedes ante mí a la mostrar.

El concejo si bien no devolvió la prenda, en primer momento no debió tener una conducta a tomar claramente determinada, pues tampoco apareció ante su señor a alegar cosa alguna. La consecuencia la declaración de rebeldía por don Diego López Pacheco y, ya sí, ante esto, la comparecencia ante el marqués de Agustín de Beteta y Domingo González de Fuente el Lobo, procuradores de Montalbanejo, para defender la actitud de su universidad, entablándose un verdadero pleito de hidalguía. El resultado era previsible, el señor feudal protegió a su vasallo y le dio por noble y por caballero.

Pero don Diego López Pacheco, marqués de Villena, no se limitó a sentenciar en virtud de los privilegios reales que ennoblecían a Juan de la Peña, lo que seguiría siendo una acaparación de competencias jurisdiccionales pero no un ennoblecimiento, sino un reconocimiento de la nobleza ya creada, pero la verdad es que al argumentar el marqués su decisión se erige en fuente creadora de nobleza política al declarar la existencia de otras causas distintas a los privilegios regios. Él mismo no nombra en ningún momento al documento que expide su chancillería como ejecutoria, que lo sería si se limitara a recoger una simple sentencia definitiva, sino que utiliza para referirse a él, el equivoco término de "carta de hidalguía".

E vos mando a vos el dicho conçejo de Montalvanejo e alcaldes e regidores e ofiçiales e omes buenos de él e a otros qualesquier conçejos, alcaldes, regidores, alguaziles, cavalleros, escuderos, ofiçiales e omes buenos de qualesquier çiudades e villas e lugares del mi marquesado e condado e de lo otros lugares de mis señoríos que le guardedes e fagades guardar al dicho Juan de la Peña e a los dichos 
sus fijos, avidos e por aver, e a los desçendientes de él y de ellos, la dicha mi carta de fidalguía e cavallería e todo lo en ella contenido, ynviolablemente para syenpre jamás.

Ciertamente no es el único caso en donde a una ejecutoria se le denomina carta, pero no creo que la terminología empleada sea arbitraria, cuando nombra igualmente a los privilegios de Enrique IV también como cartas de hidalguía o de confirmación, estableciendo similitudes que automáticamente llevan a mayores alcances.

Es evidente que no se puede centrar una afirmación en tan sólo lo anterior. Muy por encima de ello está que para el marquesado de Villena y para todos sus señoríos, López Pacheco se atreve a dar validez a unos privilegios regios derogados, a sobreponerse a la potestad real y del Reino reunido en Cortes y a refrendar, en virtud de su titularidad feudal, algo jurídicamente inexistente, volviendo a crear con ese refrendo una hidalguía, pues su apelación al privilegio enriqueño es de por sí inválida, y sin duda él, su audiencia y su chancillería lo tenían muy presente.

E porque la merçed que el rei nuestro señor le faze por la dicha su carta, ella, es capaz e ábil e él la meresçe e es bien meresçiente de ella... E porque de justiçia asy se deve fazer, yo por la presente pronunçio e declaro e mando que le sea guardada a él e a los dichos sus fijos avidos e por aver e desçendientes de él y de ellos, la dicha carta según que en ella de suso se contiene agora e para syenpre jamás... E sy contra el thenor e forma de ella fiziéredes agora ni en ningún tienpo o yntetárades de yr, mando al mi corregidor e justiçia mayor que agora es e fuere de aquí adelante e a los alcaldes e justiçias de la mi villa de Alarcón que agora son e serán de aquí adelante, que syn lo más consultar conmigo lo fagan tener e guardar e cunplir todo lo susodicho según e por la vía e forma que en la dicha carta de suso encorporada se contiene e según por mí es pronunçiado e declarado e mandado.

El marqués de Villena tiene presente la fragilidad de lo dispuesto por Enrique IV en favor de Juan de la Peña y esa convicción se convierte en expresa cuando junto a ella, como fundamento, establece otros argumentos para tener y mandar que se tenga por noble a todos los efectos y por supuesto para los efectos jurídicos, a Juan de la Peña. Lo cual supone no sólo que la carta ya no se trata de una simple sentencia, ni tampoco de una confirmación de un privilegio regio por parte de un magnate, sino que éste está creando por medio de nuevos basamentos la solidez de una nobleza que desea y ordena que se acate como nobleza jurídica. En realidad don Diego López Pacheco está dando un documento por el que se crea una hidalguía.

Los argumentos que se presentan para avalar el reconocimiento como noble del vasallo poseen todos un origen tradicionalmente medieval:

a) El origen de la hidalguía de Juan de la Peña, como la de otros linajes, se encuentra en el uso ennoblecedor y esclarecido de las armas: 
E porque a mí es noctorio el dicho Juan de la Peña aver ganado la dicha fidalguía e cavallería por exerçitar e usar el ofiçio de las armas e abtos militares, por los quales, por virtud de los tales abtos se encomençaron a ennobleçer munchos linages de homes fijosdalgo e cavalleros.

b) La actividad militar del vasallo es una dedicación continuada, no esporádica, dedicación que además mantiene en el momento de expedir el marqués su carta de hidalguía en 1472, lo que le sigue haciendo acreedor a la nobleza jurídica:

E continua usar el ofiçio de las armas como a mí es noctorio.

c) Juan de la Peña es un buen vasallo, y no sólo del rey, que sería un razonamiento lógico y simplemente necesario para que el soberano otorgase su privilegio, sino que lo es también y de manera principal del señor feudal, por lo que se hace acreedor a la hidalguía no sólo ante el poder de la Monarquía sino ante el Poder feudal para que éste último lo tenga y ordene que se le tenga por noble:

La ganó en serviçio del dicho señor rei e mio.

d) La voluntad de don Diego López Pacheco, marqués de Villena, que hace primar su potestad por encima de las potestades y leyes del Reino:

E vos mando... que le guardedes e fagades guardar al dicho Juan de la Peña e a los dichos sus fijos, avidos e por aver, e a los desçendientes de él y de ellos, la dicha mi carta de fidalguía e cavallería e todo lo en ella contenido, ynviolablemente para syenpre jamás.

Se decía al inicio de este apartado que se trataba de un caso, de un documento netamente bajomedieval y este razonamiento se debe a los múltiples vectores que influyen en él, a las muy diversas facetas que en él se atisban y comparecen.

Como texto finimedieval la fuente creadora de hidalguía que en él se reconoce como la más firme y valedera, como la absoluta según Derecho, es la Monarquía. A ella se dirigen magnate y vasallo para que el último acceda a la nobleza. No buscan fórmulas alternativas seguramente usadas con frecuencia en el pasado y que presentaban como fuente de nobleza al simple Poder feudal, ni siquiera se opta por el modesto pleito de hidalguia en el que como jurisdicción entiende el señor y por su decisión en justicia queda reconocido como noble el vasallo - cosa muy común en esos tiempos todavia tanto entre jurisdicciones municipales como señorialesen este caso si se hubiera estado ante una simple ejecutoria de hidalguía bajo el nombre de carta. Sin embargo la actividad del marqués de Villena y de su chancillería va mucho más lejos y desde el inicio queda manifestado: un señor feudal confirma y perfecciona, actuando realmente cuasi como un pcder soberano, la merced de un rey. Merced que el rey y sus Cortes habían derogado y revocado. El Poder feudal valida un documento inhábil jurídicamente y perfeccionándolo vuelve 
por su sólo mandato a poseer todos sus efectos. Cierto es que se debe tener en cuenta la posición y la especial historia de don Diego López Pacheco y de Enrique IV, pero esto no desdice la actuación del Poder feudal encarnada aquí en Villena.

No obstante el confirmante señorial reconoce la debilidad del poder regio de ese momento e incluso, compartiendo los argumentos ideológicos y jurídicos que habian aportado los procuradores de Cortes al protestar de las hidalguias y caballerías de Enrique IV, busca otros argumentos para evidenciar que la hidalguía de Juan de la Peña no estaba basada en una actividad perversa de un rey que había ennoblecido a villanos sin justas causas y lo más común por dinero. De ahí la defensa de la actividad militar, en una perfecta línea medieval y feudal, como causa preclara de nobleza, es decir no sólo el rey dio la hidalguía con justicia sino que a ésta era acreedor, independientemente de que el soberano la hubiese concedido, Juan de la Peña, y por tanto el marqués también lo tiene por noble por esto, pues es testigo de esa actividad.

Redundando en sus afirmaciones Villena considera justo y arreglado a Derecho el ennoblecimiento de su vasallo porque ese ejercicio militar de por sí ennoblecedor fue hecho y además sigue ejecutándose, al servicio del rey sí, pero sobre todo al servicio del señor feudal que en este caso decide y otorga. De manera que en la más genuina tradición medieval el servidor es recompensado no por servir a la Monarquía, lo que fue pretexto también en cualquier privilegio de la Edad Moderna, sino por servir a un señor feudal, lo cual, lo último, para el tipo de merced del que estamos tratando sería impensable ya en la Corona de Castilla en la Modernidad. Hasta el mismo privilegio de confirmación establece esa dicotomía en las cabezas a quien sirvió el vasallo, Corona y señor. Pero es que fuera del privilegio enriqueño, en el texto ya exclusivo de la carta de hidalguía de Villena, éste vuelve a ponerlo de manifiesto como razón propia que justifica su decisión y mandato y advierte y recuerda a sus concejos y en especial al de Montalbanejo, que Juan de la Peña es noble porque sirve excepcionalmente a su señor jurisdiccional y feudal.

Por último Villena habla de Justicia, de Derecho y derecho, pero por encima de todo quien habla es el marqués de Villena y él es el que sólo, en exclusiva, pronuncia, declara y manda que se guarde su carta de hidalguia, no sólo la confirmación y privilegio del rey, sino la carta de hidalguía suya, imponiendo a todos y por tanto creando para todos una nobleza, la hidalguía de Juan de la Peña, su fiel vasallo.

\section{APENDICE DOCUMENTAL}

\section{Documento I}

Ocaña, 1472, julio, 26

Carta de hidalguía y caballería dada por don Diego López Pacheco, marqués de Villena, en favor de su vasallo Juan de la Peña, vecino de Montalbanejo, por la 
que se confirma el privilegio de hidalguia y caballería otorgado por el rey Enrique IV, en Segovia, a 16 de octubre de 1470, en favor del citado Juan de la Peña.

\section{B. AHN, Consejos, Leg. 28.344}

Yo don Diego López Pacheco, marqués de Villena, conde de Santistevan, mayordomo mayor del rei, nuestro señor, a vos el conçejo, alcaldes, regidores, ofiçiales e omes buenos pecheros del mi lugar de Montalvanejo, lugar e juridiçión de la mi villa de Alarcón, bien sabedes como el rei, nuestro señor, dio una su carta de confirmaçión de fidalguía e caballería a Juan de la Peña, mi vasallo. El thenor de la qual es éste que se sygue.

Don Enrique por la graçia de Dios, rey de Castilla, de León, de Toledo, de Galizia, de Sebilla, de Córdova, de Murçia, de Jaén, el Algarve, de Algeçira, de Gibraltar, e señor de Vizcaya e de Molina, a los duques, condes, marqueses, ricos omes, maestres de las Órdenes, priores, comendadores e suscomendadores, alcaides de los castillos e casas fuertes e llanas e a los del mi Consejo e oydores de la mi Audiençia e alcaldes e alguaziles e noctarios e otras justiçias e ofiçiales qualesquier de la mi Casa e Corte e Chançillería e a todos los conçejos, corregidores e alcaldes, alguaziles, merinos, regidores, cavalleros, escuderos, ofiçiales y omes buenos de todas las çiudades e villas e lugares del marquesado de Villena e de los mis reinos e señoríos que agora son e serán de aquí adelante e a qualquier e qualesquier de vos a quien ésta mi carta fuere mostrada o el traslado de ella, sygnado de escrivano público, salud e graçia.

Sepades que Juan de la Peña, vezino de Montalvanejo, lugar e juridiçión de la villa de Alarcón, me fizo relaçión que yo le dí una mi carta de fidalguía, la qual presentó ante mí. Por la qual paresçió que fize merçed que él y sus hijos y nyetos e nietas, avidos e por aver, e los que de él e de ellos viniesen e deçendiesen para syenpre jamás, fuesen hijosdalgo noctorios de solar conosçido de vengar quinientos sueldos, según fuero de España. E oviesen e gozasen e les fuesen guardadas todas las honras e graçias e merçedes e franquezas e libertades e esençiones e prerrogativas e previlegios e preminençias e todas las / otras cosas de que han gozado e gozan e han seydo e son e fueren guardadas a cada uno de los otros omes fijosdalgo noctorios e de solar conosçido e de vengar quinientos sueldos de los dichos mis reinos, según que más largamente en la dicha mi carta se faze minçión. $E$ que después, él, estando en mi serviçio con don Diego López Pacheco, marqués de Villena, sobre el castillo e fortaleza de Mira que Alfonso de Lisón, comendador de Socovos, capitán de la que gente que por mi mandado están en el çerco del dicho castillo e fortaleza, le ovo armado cavallero. Lo qual paresçió ante mi por un testimonio firmado del dicho Alonso de Lisón, mi capitán, e signado de escrivano público, que el dicho Alfonso de Lisón, mi capitán susodicho, armó cavallero al dicho Juan de la Peña dentro de la cava de la dicha fortaleza, pendiente el conbate que en la dicha fortaleza e castillo se dio, por muchas cosas que él ende fizo e se portó muy bien como cavallero. E que entendiendo que lo que él fizo por entonçes cabia bien en él la horden e dignidad de la cavallería por aver exerçitado muchas vezes 
los abtos melitares de ella, según que fue mostrado ante mí e paresçió por el dicho testimonio. $E$ dize que se reçela que vos o alguno de vos non la queredes guardar a él e a sus fijos e a los deçendientes de él y de ellos la dicha mi carta de fidalguía e la dicha cavallería, diziendo que non deve gozar de ellos porque yo mandé rebocar todas las cartas de fidalguías que por mí fueron dadas de zierto tienpo acá, e ansymismo porque el dicho Juan de la Peña no fue armado cavallero por mí ni por persona que para ello poder tuviese. En lo qual diz que sy así pasase que resçibería grande agravio y daño, ame pedido por merçed que sobre ello le proveyese, mandándole confirmar la dicha fidalguía e la dicha cavallería porque mejor fuesen guardadas a él e a los dichos sus hijos e desçendientes de él e de ellos e le mandase proveer como la mi merçed fuese. E yo / acatando e considerando cómo a los reyes e prínçipes es propio de conosçer e remunerar los buenos e leales e señalados serviçios de sus súbditos e naturales e porque otros se esfuerçen a nos servir con toda lealtad y fedelidad, según que el dicho Juan de la Peña lo ha hecho e paresçe por la dicha escriptura de testimonio e espero que lo fará de aquí adelante. $E$ otrosí, por le fazer bien e merçed, tóvilo por bien e de mi propio motuo e çierta çiençia e poderío real absoluto de que quiero usar e uso en esta parte como rey e señor, confirmo e apruevo al dicho Juan de la Peña e a los dichos fijos e nietos e nietas avidos e por aver e a los desçendientes de él y de ellos, la dicha mi carta de merçed de la dicha fidalguía que por mi le fue dada e todo lo en ella contenido e cada cosa e parte de ello. E quiero e es mi voluntad que les vala e sea firme e valedera del día de la data de ella para syenpre jamás. E ansymismo del dicho mi propio motuo e çierta çiençia e poderio real absoluto de que quiero usar e uso, le apruebo e afirmo e confirmo al dicho Juan de la Peña la dicha cavallería e lo he por cavallero e es mi merçed que él e los dichos sus fijos que él ovo antes de la dicha cavallería e que oviere después que ella e los desçendientes de él y de ellos desde el día que por el dicho Alonso de Lisón, mi capitán, el dicho Juan de la Peña fue armado cavallero para syenpre jamás, gozen de todas las honras e libertades e esençiones e franquezas e preminençias e previlegios de que se han gozado e gozan cada uno de los otros cavalleros por mi armados. Porque mi merçed es que gozen de todo ello enteramente, asi e como sy por mi mano propia fuese armado cavallero, ca por la presente le afirmo e confirmo al dicho Juan de la Peña e le apruevo la dicha cavallería que el dicho comendador Alfonso de Lisón lo armó como de suso / es dicho. E quiero y es mi merçed e voluntad que aya tanta fuerça $e$ vigor e efecto como sy le yo oviere armado cavallero en mi Cámara o en guerra, guerreada contra moros e otras gentes de fuera de mis reinos, con las solenidades de las leyes de los dichos mis reynos quieren y mandan. Y por más honrar e ennosbleçer al dicho Juan de la Peña e sy nesçesario e conplidero le es, agora de nuevo, yo por esta mi carta lo armo e fago cavallero.

E vos mando a todos e a cada uno de vos que guardedes e cunplades e fagades guardar e cunplir al dicho Juan de la Peña e a los dichos sus fijos, avidos e por aver, e a los desçendientes de él y de ellos, la dicha mi carta de fidalguía e la dicha cavallería e lo ayades por cavallero armado por mi mano y le guardedes e fa- 
gades guardar a él e a los dichos sus hijos, avidos e por aver, e a los deçendientes de él y de ellos, todas las honras, graçias e merçedes e franquezas e libertades, prerrogativas e esençiones e preheminençias e previlegios e todas las otras cosas e cada una de ellas de que han gozado e gozan e son e fueron guardadas a los omes fijosdalgo de solar conosçido e de bengar quinientos sueldos de los dichos mis reinos e a los cavalleros por mí armados, como quier que no tenga ni mantenga cavallo ni armas ni las otras cosas que deven guardar e mantener por razón de la dicha cavallería.

E contra el thenor e forma de ellas le no vayades, ni pasedes, ni consyntáys yr ni pasar en algún tienpo, ni por alguna manera, ni causa, ni rasón, ni color que sea e que lo asy fagades e cunplades no enbargante la dicha rebocaçión que yo fize de las dichas fidalguías, ni qualesquier leyes e hordenanças fechas e hordenadas por el rey don Juan, mi señor e mi padre que Dios aya, ansy en la çiudad de Çamora como en la villa de Valladolid que fabla sobre la razón de los cavalleros, ni las cláusulas e firmezas e abrogaçiones e derogaçiones en ellas e en cada una de ellas contenidas, e ansymismo / no enbargante qualesquier leyes e fueros e derechos e hordenamientos e premáticas sançiones fechas e hordenadas por los otros reyes mis anteçesores e que yo aya fecho o fiziere de aqui adelante a petiçión de los procuradores de las çiudades e villas de mis reinos, ansy en Cortes como fuera de Cortes, que en contrario sean o ser puedan. Ni asymismo no enbargante las leyes que dizen que las cartas dadas contra ley o fuero o derecho deven ser obedesçidas e no cunplidas, e que las leyes e fueros e derechos valederos non pueden ser derogados ni revocados, salvo por Cortes. Que yo del dicho mi propio motuo e çierta çiençia, aviéndolo todo aquí por expresado e declarado asy como si de ello e de cada una cosa de ello aquí fuese hecha expresa e espeçial minçión, dispenso con ello e lo alço e quito e anulo e abrogo e derogo en quanto a esto atañe o atañer puede. $E$ ansymismo con otra qualquier cosa de qualquier natura, efecto o calidad e misterio que le pudiese o pueda enbargar o perjudicar en qualquier manera, $e$ alço e quito toda obrriçión e subrriçión e todo otro obstáculo e ynpedimento, asy de fecho como de Derecho que a lo susodicho o a alguna cosa o parte de ello enbargar pudiese, e suplo qualesquier defectos e otras qualesquier cosas, ansy de sustançia como de solenidad, nesçesarias e cunplideras e provechosas de se suplir para perpetua validaçión e corroboraçión de todo lo en esta dicha mi carta contenido e de cada cosa e parte de ello.

E los unos ni los otros non fagades ni fagan ende al por alguna manera, sopena de la mi merçed e de privaçión de los ofiçios e de confiscaçión de los bienes de los que lo contrario fisyeren, para la mi Cámara. E demás mando al home que vos ésta mi carta / mostrare o el dicho su traslado, sygnado como dicho es, que vos enplaze que parescades ante mí en la mi Corte o doquier que yo sea, del día que vos enplazare fasta quinze días primeros syguientes so la dicha pena, so la qual mando a qualquier escrivano público que para esto fuere llamado, que dé, ende, al que vos la mostrare testimonio sygnado con su sygno porque yo sepa cómo se cunple mi mandado. 
Dada en Segovia, a diez y seys días de otubre, año del nasçimiento de nuestro Sseñor Ihesu Christo de mil e quatroçientos e setenta años. Yo el rey. Yo Juan de Oviedo, secretario del rey, nuestro señor, la fize escrivir por su mandado. $E$ en las espaldas de la dicha carta estavan escriptos esto nonbres que se syguen: Registrada. Juan de Sevilla Garçia, chançiller.

E por virtud de la dicha carta fuystes requeridos por el dicho Juan de la Peña que la obedeçiésedes e guardásedes e cunpliésedes según que en ella se contiene, e, en cunpliéndola, le guardásedes la dicha su fidalguía e cavallería que de suso se faze minçión. La qual le guardastes çierto tienpo según que ante mí paresçió, e de poco tienpo acá le prendastes por el pecho e vos requirió que le tornásedes la dicha su prenda, que ansy ynjustamente le aviades fecho. Lo qual no quisystes hazer. Sobre lo qual el dicho Juan de la Peña paresçió ante mí e se me querelló de lo susodicho, sobre lo qual yo mandé dar mi carta para vos el dicho conçejo, para que luego diésedes e restituyésedes la dicha prenda al dicho Juan de la Peña, o que sy alguna razón teníades para vos para lo no dever asy fazer e cunplir, que dentro de nueve días después que vos fuese notificada, paresçiésedes ante mi a la mostrar. E no enbargante que la dicha carta vos fue notificada, la dicha prenda no quisystes / dar ni restituir al dicho Juan de la Peña. Antes suplicastes de la dicha mi carta para ante mí. $E$ dentro de los dichos nueve días no paresçistes. $E$ el dicho Juan de la Peña acusó çiertas rebeldias e çerró contra vos. E después paresçieron ante mí Agustín de Beteta e Domingo Gonzales de Fuente el Lobo, vuestros procuradores con poder bastante vuestro, e purgaron las dichas rebeldías e alegaron çiertas razones, diziendo que la non deviades cunplir por çiertas razones que los dichos vuestros procuradores alegaron ante mí, según más largamente se contiene en las petiçiones que ante mí presentaron los dichos vuestros procuradores en este caso e están puestas en el proçeso que ante mí en este caso pasó e contendieron ante mi con el dicho Juan de la Peña fasta que concluyeron. E porque a mi es noctorio el dicho Juan de la Peña aver ganado la dicha fidalguía e cavalleria por exerçitar e usar el ofiçio de las armas e abtos militares, por los quales, por virtud de los tales abtos se encomençaron a ennobleçer munchos linages de homes fijosdalgo e cavalleros, e porque la merçed que el rei nuestro señor le faze por la dicha su carta, ella, es capaz e ábil e él la meresçe e es bien meresçiente de ella pues que la ganó en serviçio del dicho señor rei e mío e usa e continua usar el ofiçio de las armas como a mí es noctorio. E por que de justiçia asy se deve fazer, yo por la presente pronunçio e declaro e mando que le sea guardada a él e a los dichos sus fijos avidos e por aver e desçendientes de él y de ellos, la dicha carta según que en ella de suso se contiene agora e para syenpre jamás. E vos mando a vos el dicho conçejo de Montalvanejo e alcaldes e regidores e ofiçiales e omes buenos de él e a otros qualesquier conçejos, alcaldes, regidores, alguaziles, cavalleros, escuderos, ofiçiales e omes buenos de qualesquier çiudades e villas e lugares del mi marquesado e condado e de los otros lugares de mis señorios que le guardedes e fagades / guardar al dicho Juan de la Peña e a los dichos sus fijos, avidos e por aver, e a los desçendientes de él y de ellos, la dicha mi 
carta de fidalguía e cavallería e todo lo en ella contenido, ynviolablemente para syenpre jamás.

E contra el thenor e forma de ella no vayades, ni pasedes, ni consyntáys yr ni pasar, agora ni de aquí adelante en algún tienpo, ni por alguna manera ni razón que sea y si algunas prendas contra el thenor e forma de ella le avedes tomadas e sacadas, yo vos mando que luego se las dedes e tornedes e restituyades con efecto syn costa alguna. $E$ vos mando que luego lo quitedes de qualesquier padrones que lo tengades puesto en que están los pecheros e lo pongades en los padrones de los fijosdalgo e le no echedes pechos ni tributos algunos, reales ni conçejales, que a pecheros pertenescan pagar, salvo en aquellas cosas que los cavalleros e fijosdalgo deven pechar e contribuir e non en otras cosas algunas. Por manera que entera e cunplidamente le sea guardada la dicha carta que de suso se contiene e todas las cosas en ella contenidas. E sy contra el thenor e forma de ella fiziéredes agora ni en ningún tienpo o yntentárades de yr, mando al mi corregidor e justiçia mayor que agora es e fuere de aquí adelante e a los alcaldes e justiçias de la mi villa de Alarcón que agora son e serán de aquí adelante, que syn lo más consultar conmigo to fagan tener e guardar e cunplir todo lo susodicho según e por la vía e forma que en la dicha carta de suso encorporada se contiene e según por mí es pronunçiado e declarado e mandado.

E los unos nin los otros non fagades ni fagan ende al por alguna manera, sopena de la mi merçed e de / diez mil maravedís para la mi Cámara a cada uno de los que lo contrario hizieren.

Fecha en la villa de Ocaña a veynte e seys días de julio, año del nasçimiento de nuestro Salvador lhesu Christo, de mil e quatroçientos e setenta e dos años. El marqués. Por mandado del marqués, mi señor, Diego de Porras.

\section{Documento II}

Castillo, 1476, febrero, 11

Carta otorgada por el duque de Escalona y marqués de Villena dirigida al concejo de la villa de Belmonte por la que ordena que se tenga excusado de cualquier pecho, en contra de las ordenanzas y usos locales, a su criado Juan de la Peña, vecino de Belmonte, en la misma forma y manera que sus otros excusados.

\section{B. AHN, Consejos, Leg. 28.344}

Yo don Diego López Pacheco, duque de Escalona, marqués de villena, conde de Santisteban, mayordomo mayor del rey nuestro señor y del su Consejo, fago saber a vos el conçejo, justiçia, regidores, cavalleros, escuderos, ofiçiales y homes buenos de la mi villa de Belmonte que yo fize y fago merçed a Juan de la Peña, mi criado, de todos los marevedís que le cupiese a pagar de todos los pechos y de- 
rramas que le repartésedes en esa dicha mi villa desde el día de san Miguel de setienbre próximo pasado en adelante para en toda su vida, por serviçios que me ha hecho y faze de cada día. Por tanto yo vos mando que le non repartades ni demandadedes al dicho Juan de la Peña, vezino de esa dicha villa, maravedís algunos de pecho ni derrama ni otro tributo alguno real ni conçegil, dende el dicho día de San Miguel de setienbre próximo pasado en adelante para en toda su vida e sy algunos maravedís le tenéys repartidos yo vos mando que se los no demandedes. $Y$ por quanto esa dicha mi villa tiene previlegio que todos los que tuvieren bienes pechen y contribuyan por ellos y porque mi voluntad y querer es que el dicho previlegio se guarde, por esta carta vos mando que de qualesquier maravedís que oviéredes a dar en cada un año, ansy de serviçio como en otra qualquier manera vos entreguedes y tomedes los maravedis que al dicho Juan de la Peña y a sus bienes le copiere a pagar de los dichos repartimientos y derramas cargando según que a otros mis criados que de mí tienen semejantes merçedes acostunbrades repartir. E por esta mi carta o por el traslado de ella sygnado de escrivano público mando al mi contador y ofiçiales que vos resçiban en quenta los dichos maravedís que al dicho Juan de la Peña y a sus bienes cupiere pagar de los dichos pechos y derramas e por esta dicha mi carta mando al alcaide de la fortaleza de la dicha villa de Belmonte / y a las otras justiçias que agora son y serán de aquí adelante que vos conpelan y apremien a guardar y cunplir todo lo en esta mi carta contenido. $E$ los unos nin los otros non çesedes de lo ansy fazer y conplir sopena de la mi merçed y de diez mil maravedis para la mi Cámara a cada uno de vos por quien fincare de lo ansy fazer y cunplir.

Dada en la mi villa del Castillo a honze días del mes de hebrero, año del nasçimiento de nuestro Salvador thesu Christo de mil e quatroçientos y setenta y seys años. El marqués. Yo Julián Vázquez de Medina, secretario del marqués mi señor la fize escrivir por su mandado. 